\title{
Effects of Organic Pesticides on Enchytraeids (Oligochaeta) in Agroecosystems: Laboratory and Higher-Tier Tests
}

\section{OPEN ACCESS}

Edited by: Johann G. Zaller,

University of Natural Resources and

Life Sciences, Vienna, Austria

Reviewed by: Bruno B. Castro,

University of Minho, Portugal Bruno Silva Nunes, Center of Studies of the Environment and the Sea (CESAM), University of Aveiro, Portugal

*Correspondence: Jörg Römbke j-roembke@ect.de

Specialty section:

This article was submitted to Agroecology and Land Use Systems,

a section of the journal

Frontiers in Environmental Science

Received: 17 February 2017 Accepted: 24 April 2017

Published: 15 May 2017

Citation:

Römbke J, Schmelz RM and Pélosi C (2017) Effects of Organic Pesticides on Enchytraeids (Oligochaeta) in Agroecosystems: Laboratory and Higher-Tier Tests.

Front. Environ. Sci. 5:20. doi: 10.3389/fenvs.2017.00020

\author{
Jörg Römbke ${ }^{1 *}$, Rüdiger M. Schmelz ${ }^{1,2}$ and Céline Pélosi ${ }^{3}$ \\ ${ }^{1}$ ECT Oekotoxikologie GmbH, Flörsheim, Germany, ${ }^{2}$ Grupo de Investigación en Biología Evolutiva, Facultad de Ciencias, \\ Centro de Investigaciones Cientificas Avanzadas (CICA), Universidad de A Coruña, A Coruña, Spain, ${ }^{3}$ UMR ECOSYS, INRA, \\ AgroParisTech, Université Paris-Saclay, Versailles, France
}

Enchytraeidae (Oligochaeta, Annelida) are often considered to be typical forestliving organisms, but they are regularly found in agroecosystems of the temperate regions of the world. Although less known than their larger relatives, the earthworms, these saprophagous organisms play similar roles in agricultural soils (but at a smaller scale), e.g., influencing soil structure and organic matter dynamics via microbial communities, and having a central place in soil food webs. Their diversity is rarely studied or often underestimated due to difficulties in distinguishing the species. New genetic techniques reveal that even in anthropogenically highly influenced soils, more than 10 species per site can be found. Because of their close contact with the soil pore water, a high ingestion rate and a thin cuticle, they often react very sensitively to a broad range of pesticides. Firstly we provide a short overview of the diversity and abundance of enchytraeid communities in agroecosystems. Afterwards, we explore the available data on enchytraeid sensitivity toward pesticides at different levels of biological organization, focusing on pesticides used in (mainly) European agroecosystems. Starting with non-standardized studies on the effects of pesticides on the sub-individual level, we compile the results of standard laboratory tests performed following OECD and ISO guidelines as well as those of higher-tier studies (i.e., semi-field and field tests). The number of comparable test data is still limited, because tests with enchytraeids are not a regulatory requirement in the European Union. While focusing on the effects of pesticides, attention is also given to their interactions with environmental stressors (e.g., climate change). In conclusion, we recommend to increase the use of enchytraeids in pesticide risk assessment because of their diversity and functional importance as well as their increasingly simplified use in (mostly standardized) tests at all levels of biological organization.

Keywords: potworms, Annelida, Clitellata, plant protection products, laboratory, field, ecotoxicology

\section{INTRODUCTION}

Plant protection products (PPP) or agricultural pesticides are commonly used in conventional agriculture world-wide, and their detrimental effects on non-target organisms are a major concern not only from a biodiversity perspective, but also considering the reduction of functions and services provided by soil ecosystems (Turbé et al., 2010; EFSA Panel on Plant Protection Products and their Residues (PPR) et al., 2017). 
Knowledge of pesticide effects on non-target organisms is therefore essential for sustainable agriculture. The role of soil fauna for maintaining ecosystem services has been studied intensively in the last decade (Mulder et al., 2011), with emphasis on the macrofauna such as earthworms (Brussaard, 2012). However, smaller-sized organisms such as enchytraeids also contribute to the functioning of agro-ecosystem (Didden, 1993). Enchytraeids occur worldwide in all soils with sufficient oxygen, moisture and nutrient supply, and they are regularly found even in intensively managed conventional agriculture (Pelosi and Römbke, 2016). The aim of this review is to gather all available information on pesticide effects on this important group of soil organisms.

Pesticides can harm non-target organisms either directly, by impacting their gene expression, behavior, reproduction, life cycle, or indirectly, by modifying interactions between individuals and populations (e.g., by affecting the prey of organisms but not the predators themselves). Laboratory single-species tests do not allow to address properly these complex effects of chemical exposure at the community level or higher, since they focus on single species under highly standardized conditions. So we have to understand what happens at the individual level but also to reveal the cascade of responses at the lower levels of biological organization and to adopt a more holistic assessment of higher hierarchical levels of ecological organization, i.e., populations, communities, ecosystems (European Commission, 2009). In order to manage ecosystem services successfully, we must understand how changes in community structure collectively affect the level and stability (resilience) of the ecosystem services over space and time (Kremen, 2005).

Enchytraeids or potworms (Enchytraeidae, Oligochaeta, Annelida) belong to the soil mesofauna (body diameter 0.1$2 \mathrm{~mm}$ ). Today, about 206 species are listed in the key for terrestrial potworms of Europe (Schmelz and Collado, 2010) and 126 are known from Germany (Römbke et al., 2013). Probably 50 of them can be classified as common for Central Europe (Didden et al., 1997). The basis of enchytraeid taxonomy is the monograph of Nielsen and Christensen $(1959,1961,1963)$ but since then, our knowledge has increased considerably with the description of new species (52 for Europe, Schmelz, personal comm.), enhanced morphological diagnoses (e.g., Rota and Healy, 1999), systematic revisions (e.g., Schmelz, 2003), and an updated guide to species identification (Schmelz and Collado, 2010). As in many other invertebrate groups it seems that a high cryptic diversity exists in the Enchytraeidae (Collado et al., 2012; Martinsson et al., 2015).

In this review we cover the effects of organic pesticides on enchytraeids in different land-use types and geographical regions. Each of these key terms is defined as follows: Pesticides are all chemicals being used against "harmful" organisms in agro-ecosystems, in particular herbicides, insecticides, and fungicides. We do not include copper, which is used as a fungicide, especially in vineyards. However, its fate and modeof-action differs strongly from organic pesticides. Also effects of genetically modified plants/organisms are not addressed since this issue has already been covered in a review by Pelosi and Römbke (2016). Regarding land-use types, our review focuses on agro-ecosystems, i.e., crop sites, mainly on cereal crops, but also grasslands. Forests and urban sites were excluded, but information from such sites was sometimes included, in particular regarding methodological questions. All geographical regions with agricultural sites world-wide are included. However, with few exceptions, the majority of studies has been performed in the Continental and Atlantic biogeographic regions of Europe. Finally, all species of the family Enchytraeidae which occur in terrestrial habitats are covered. Taxonomic nomenclature follows Schmelz and Collado (2012), if not otherwise mentioned. It should be noted that we do not compare the sensitivity of enchytraeids toward pesticides with other soil invertebrate groups. Such comparisons are possible when looking at the results of standardized OECD (or ISO) tests, especially those with earthworms (Eisenia fetida/andrei), springtails (Folsomia candida) or predatory mites (Hypoaspis aculeifer). Such information can be found in Frampton et al. (2006) and Jänsch et al. (2006) for laboratory and field studies, respectively. Another more recent compilation has been made by Jarratt and Thompson (2009), who in particular compared the sensitivity of earthworms and enchytraeids toward pesticides.

To summarize, the aims of this review are (i) to give a short overview on the ecology, diversity and abundance of enchytraeid communities in agroecosystems, (ii) to compile ecotoxicological testing methods with enchytraeids, (iii) to list and discuss the effects of organic pesticides on enchytraeids at different levels of biological organization (including bioaccumulation). In this context, attention is also given to the interactions between other environmental stress factors (e.g., climate change) and pesticides. After summarizing these findings, the knowledge gaps regarding the use of enchytraeids in pesticide ecotoxicology will be pinpointed.

\section{ENCHYTRAEID ECOLOGY}

The ecology of terrestrial Enchytraeidae was firstly summarized by Didden (1993), but already in those days the main focus was on enchytraeids in forests. In such soils, potworms can occur in very high densities, up to several hundred thousand individuals per square meter (Peachey, 1963). Some species, e.g., Cognettia sphagnetorum in acid coniferous forests of Central and Northern Europe, play a key role in processes such as the decomposition of organic matter and nutrient cycling (Laakso and Setälä, 1999). In less acid soils, i.e., those in which earthworms do occur in higher numbers and biomass, enchytraeids are often less abundant and, thus, were considered of being less important (Petersen and Luxton, 1982). Since crop sites are usually kept within the neutral $\mathrm{pH}$-range by fertilizing and liming, species with a preference for such soils are dominating, in particular those belonging to the genera Fridericia and Enchytraeus. According to Schärffenberg (1950) and Friberg et al. (2009), they are able to feed on plantpathogenic nematodes and fungi at such sites.

In comparison to other land-use types the enchytraeid community of agricultural sites has rarely been studied (Pelosi and Römbke, 2016). Fortunately, in most cases standardized or at least very similar sampling methods were used (International 
Organization for Standardization, 2007). Regular samplings have been made in The Netherlands (Schouten et al., 1999; Rutgers et al., 2008) and in Germany (Graefe, 1993; Römbke et al., 2000; Ruf et al., 2000; Graefe and Beylich, 2003). As a rough estimate and based on reviews of Petersen and Luxton (1982) and Römbke et al. (2002), the mean annual abundance at crop sites varies between 2,000 and $30,000 \mathrm{ind} / \mathrm{m}^{-2}$ with a biomass ranging from 110 to $640 \mathrm{mg}$ dry weight $(\mathrm{DW}) / \mathrm{m}^{2}$. Depending on the soil properties, especially the $\mathrm{pH}$ value, these numbers can be $2-4$ times higher in grasslands.

In general, not much is known about the diversity (species number, community composition etc.) of enchytraeids in agricultural soils, since the first key of European species was only published in the Late Fifties (Nielsen and Christensen, 1959, 1961, 1963). This situation improved only recently (Schmelz and Collado, 2010). Enchytraeid communities at crop sites have been classified as "impoverished" grassland communities (Jänsch et al., 2005). Römbke et al. (2013), after reviewing their occurrence all over Germany, evidenced the similarity of enchytraeid communities at arable and grassland sites. Recently, Pelosi and Römbke (2016) supported this view when reviewing the suitability of enchytraeids as indicators for agricultural management practices. Table 1 exemplifies a "typical" enchytraeid community at crop sites in Germany, listing percentages of species occurrence and comparing them with those in grassland and deciduous as well as coniferous forests. Both the dissimilarity of the two forest sites vs. the two openland sites as well as the similarity of crop and grassland sites are evident. Notable differences between the latter two are lower densities of litter dwellers (e.g., Buchholzia appendiculata) and higher densities of very small species (e.g., Enchytronia sp.) and r-strategists (Enchytraeus buchholzi) at crop sites.

According to Graefe and Schmelz (1999), enchytraeid species differ with respect to their preferred occurrence in the soil profile. For convenience, these preferences can be combined into three groups as follows:

LD: litter dwellers (e.g., Buchholzia appendiculata, Cognettia sphagnetorum);

SD: soil dwellers (e.g., Marionina clavata, Fridericia bulboides, Fridericia galba);

IS: intermediate species (e.g., Henlea perpusilla, Enchytraeus christenseni).

Litter dwellers have sigmoid chaetae, they often move rapidly and with strong body contractions, and asexual reproduction by fragmentation is common. Litter dwellers usually feed on slightly to strongly decomposed remains of plants and on microorganisms (bacteria and fungi), $80 \%$ of their diet being regarded to consist of micro-organisms and $20 \%$ of dead organic matter (Standen, 1973; Didden, 1993).

Soil dwellers are usually found in the uppermost $10 \mathrm{~cm}$ of the mineral soil, but exceptional depths down to $60-145 \mathrm{~cm}$ have been recorded (Dózsa-Farkas, 1991). Chaetae are straight distally, and body movements are often slower than those of litter dwellers. Some species are small, stress-tolerant worms (e.g., some Enchytraeus sp.), while Fridericia-species live in slightly acid to basic soils and vary considerably in size (Schmelz, 2003). Large species of this genus have strong body musculature, used for burrowing. Fridericia is by far the richest terrestrial genus of the family; up to now only few differences in habitat preferences have been found among the individual species. Most soil dwellers reproduce sexually. The diet is less well-known than in litterdwellers, but seems to consist also of micro-organisms and dead organic matter (Schmidt et al., 2004).

Intermediate species occur in mineral soil and the organic layer. They form a heterogeneous group consisting mainly of r-strategists that often live close to the soil surface, independently whether there is a litter layer or not. Many intermediate species have short generation cycles, because of asexual reproduction, including fragmentation. Especially species of the genus Enchytraeus are well-known as indicators of stress, e.g., at grassland sites close to roads (Jänsch et al., 2005; Schlaghamerský, 2015). Not much is known about their feeding preferences, but many species of the genus Enchytraeus, for example, E. albidus or E. crypticus, can be bred in the laboratory for a long time on rolled oats.

Since the mid-fifties of the last century it is known that enchytraeids are found in clusters, meaning that there are considerable differences in their horizontal distribution on a small scale (Nielsen, 1954; Peachey, 1963). According to Didden (1993), they are occurring in more or less randomly distributed multispecies clusters of $100-1,000 \mathrm{~cm}^{2}$ at arable sites. These differences may depend either on the heterogeneous distribution of resources (e.g., food) or on soil parameters (Chalupský and Lepš, 1985). However, Schrader et al. (2005) did not find a positive correlation between soil properties (e.g., sand content, amount of carbon of soil moisture) and the distribution of enchytraeids at German crop sites. Clusters may depend on reproduction activities, such as concurrent hatching from cocoons deposited in clusters (Nielsen, 1954).

The vertical distribution of enchytraeids at crop sites is strongly influenced by plowing, since organic matter is transported to deeper layers (Didden et al., 1997). As a result, the usual distribution found at sites without plowing-high densities close to the surface with decreasing numbers in deeper layerscan be changed to a more or less homogeneous density of enchytraeids within the plowing layer, but only as long as food is available there. Vertical migration of potworms is also caused by climatic factors (temperature, moisture) (Lagerlöf et al., 1989) and anthropogenic stress, such as pesticides applied to the soil surface (Römbke and Federschmidt, 1995).

Climatic factors, mediated by soil moisture and soil properties (e.g., $\mathrm{pH}$ ) dominate the occurrence and activities of enchytraeids (Graefe and Schmelz, 1999; Maraldo and Holmstrup, 2010). In Central Europe, their population dynamics usually follow a seasonal pattern determined by temperature and precipitation: maxima occur in spring and autumn, while minima are observed in summer (caused by low moisture levels in soil) and in winter (because of low soil temperatures, especially when a snow cover is missing) (Nielsen, 1955; Didden, 1993). At grasslands and crop sites this pattern is often modified due to management practices (Pelosi and Römbke, 2016). 
TABLE 1 | Species number, species composition, and percentage of species occurrence of enchytraeids at four land-use forms/habitat types in Germany (1st hierarchal level of habitat classification, juveniles not included), from Römbke et al. (2013).

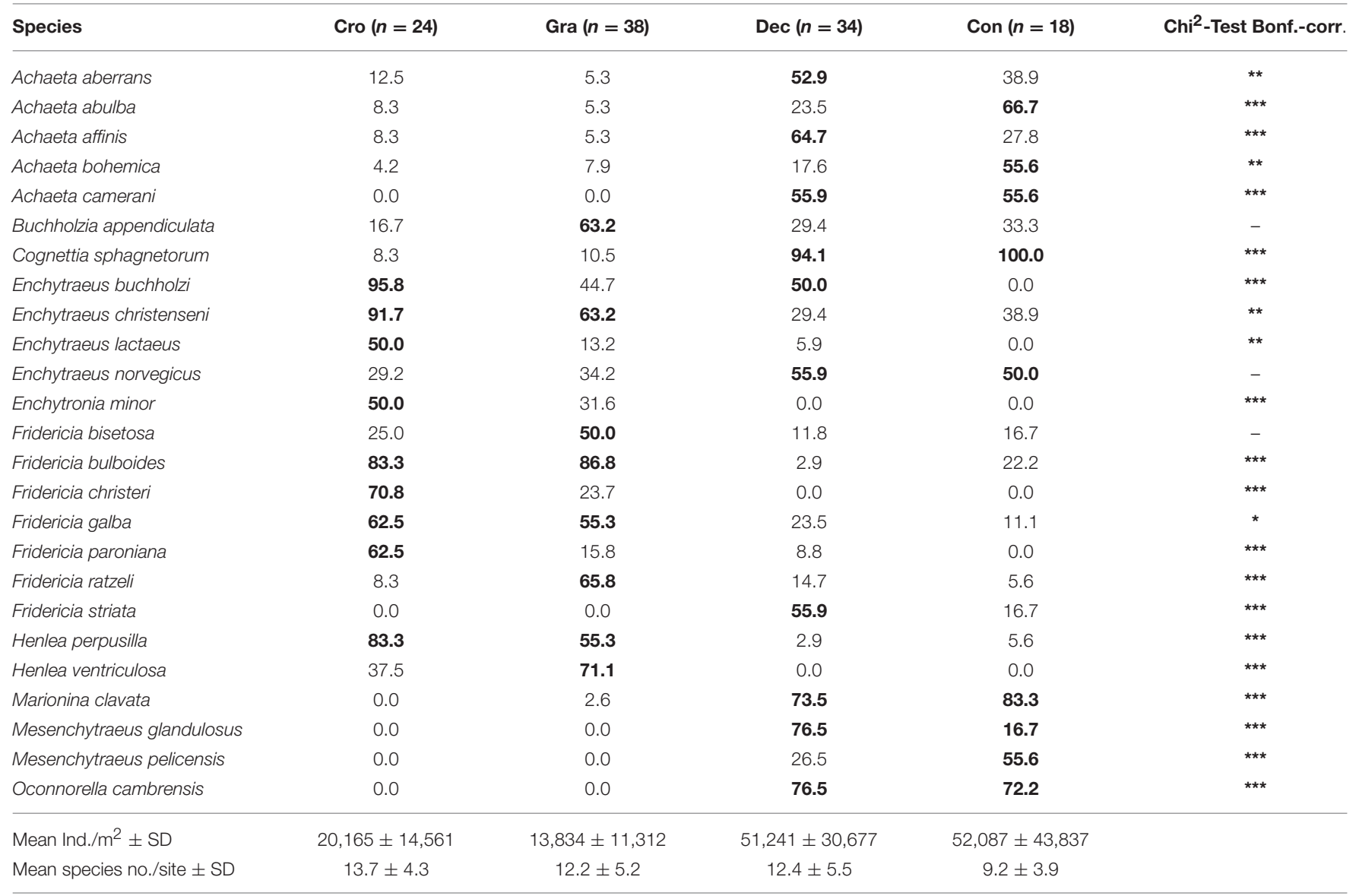

Cro, Crop sites; Gra, Grassland sites; Dec, Deciduous forest sites; Con, Coniferous forest sites. Typical species (= those with a frequency of more than $50 \%$ of all sites): given in bold. Asterisks indicate a statistically significant influence of habitat type on species distribution at ${ }^{*} p<0.05,{ }^{\star *} p<0.01$, and ${ }^{\star * \star} p<0.001$.

Enchytraeids can be very important for soil functions such as maintaining soil structure and porosity, especially when earthworms are not abundant. For example, Van Vliet et al. (1993) and Topoliantz et al. (2000) found that potworms increase porosity through their tunneling activity and their deposition of fecal pellets, thus preparing micro-sites of high fertility. This activity could also influence the distribution of plant roots in the uppermost centimeter of the soil. Didden (1990) concluded that Enchytraeus buchholzi contributes to soil structure in much the same way as earthworms-just on a smaller spatial scale. Enchytraeids also influence nutrient-cycling processes, as demonstrated by high mineralization rates measured in the fecal pellets of Buchholzia appendiculata (Marinissen and Didden, 1997). Thus, enchytraeids can be classified as "biological regulators," i.e., they regulate in particular the abundance and activity of microbes through their feeding (Turbé et al., 2010).

\section{HISTORICAL BACKGROUND: ENCHYTRAEIDS IN PESTICIDE TESTING}

Among the first regulatory requirements for the risk assessment of pesticides neither soil organisms in general nor enchytraeids in particular played an important role. For example, in the first European Union document describing tests to be performed for pesticides (Commission of the European Communities, 1991), only tests with microorganisms, plants and earthworms were listed. Already 20 years earlier, the huge taxonomic and ecological complexity of soil organism communities became more and more obvious, best visible in the outcome of long-term research projects on the influence of acid rain on forest soils (e.g., Abrahamsen and Thompson, 1979; Bengtsson and Rundgren, 1982; Standen, 1984; Chalupský, 1989). Both high numbers and central ecological roles supported the idea to use enchytraeids in standard ecotoxicological tests. Although, lack of taxonomical knowledge and breeding difficulties hampered the development of test methods, the number of enchytraeid studies on the effects of chemicals started to grow, based on the experience made in acid rain research, and reached a peak in the late nineties. Within a short period of time, laboratory tests were developed. Since then, several reproduction tests have been internationally standardized (American Society for Testing and Materials, 2004; International Organization for Standardization, 2004; Organisation for Economic Co-operation and Development, 2004; Associação Brasileira de Normas Técnicas, 2012). In 
addition, a standard semi-field test (Schaeffer et al., 2010) has been proposed, but so far, no field test is available. However, the inclusion of enchytraeids in the earthworm field test has been proposed (International Organization for Standardization, 1999). In parallel, OECD allows the use of enchytraeid species (besides earthworms) in soil bioaccumulation tests (Organisation for Economic Co-operation and Development, 2010). Currently the Enchytraeid Reproduction Test (ERT) is listed as an alternative or addition to earthworm tests in several regulations (e.g., European Plant Protection Organisation, 2003; VICH, 2005; European Chemicals Agency, 2014; EFSA Panel on Plant Protection Products and their Residues (PPR) et al., 2017).

The need for enchytraeid tests in pesticide may increase in the future, since environmental risk assessment is currently changing: now, the main theoretical approach regarding the evaluation of ecological functions of organisms is the Ecosystem Service Approach (Millennium Ecosystem Assessment, 2005). Organism groups can be classified regarding their specific functions. According to the European Food and Safety Authority (EFSA Panel on Plant Protection Products and their Residues (PPR) et al., 2017), discussing further requirements for the registration of pesticides in Europe, enchytraeid populations or functional groups play an important role regarding the following functions at in-field sites (i.e., areas which are directly impacted by pesticides): biodiversity, genetic resources, cultural services, soil structure, nutrient cycling and food-web support. In contrast, they are considered of minor importance for pest control and natural attenuation. For all off-field areas (i.e., areas adjacent to sprayed fields, which could be grassland, forest etc.) all above-mentioned functions have to be protected.

\section{MATERIALS AND METHODS}

A literature review was carried out on the basis of keywords in ISI Web of Knowledge, using the "All Databases" option, with the following formula: "enchyt* or potworm* and pesticid* or herbicid* or fungicid* or molluscicid* or nematicid* or insecticid $^{*}$ in Topics. In total, 2,741 publications were found. In a first step, publications were sorted and classified according to title, keywords and abstract. This selection revealed very different numbers for the specific parts of the review. For the individual and population levels, 226 papers were selected, while less than 15 publications were interesting for the assessment of pesticide effects on enchytraeids at the community level. In parallel, those authors which have been identified as relevant for our topic, were checked again. Afterwards, publication lists regarding Enchytraeidae in general (e.g., Schoch-Bösken and Römbke, 1993) or their use in ecotoxicology (e.g., Römbke, 2003) were checked. Special attention was given to the four reviews on their reaction to pesticides (i.e., Didden and Römbke, 2001; Frampton et al., 2006; Jänsch et al., 2006; Jarratt and Thompson, 2009). At the end, information from 302 papers was used for this review. About $5 \%$ of this list were not found via literature search but due to personal contacts (mainly older work or diploma reports).
The pesticides covered in this review are organic chemicals. We decided to exclude copper despite the fact that for more than 100 years it has been the active ingredient in a fungicide product, originally known as "Bordeaux Mixture." There is a huge amount of information available regarding the effects of copper on soil organisms in general (especially earthworms), but its effects on enchytraeids when sprayed as a pesticide are not yet covered. Copper is an essential element at low concentrations but toxic at high concentrations (Hopkin, 1989). Because of this complexity and the difficult distinction between effects of freshly sprayed copper fungicides and copper from other sources we decided that this topic requires a more detailed treatment than can be provided in our review. Sulfur and sulfur-based formulations were not explicitly looked for but they were not excluded either.

\section{EFFECTS OF ORGANIC PESTICIDES AT DIFFERENT ORGANIZATION LEVELS}

\section{Response at the Sub-Individual Level}

To our knowledge, the effects of pesticides on enchytraeids at sub-individual levels (i.e., molecular and cellular levels) have been addressed by only one Portuguese-Danish team. They investigated enchytraeid molecular and biochemical mechanisms in response to pesticide exposure using differential gene expression, as well as defense and cell injury biomarker activities (e.g., Howcroft et al., 2011; Novais et al., 2012c, 2014).

Recently, the Enchytraeid Reproduction Test (ERT) was modified in a way that embryotoxicity is covered (Gonçalves et al., 2015), measuring endpoints such as embryo development, number of embryonic structures, Calcium (Ca) channels quantification and hatching success in combination with macroscopic monitoring, histological and immunohistochemistry analysis. However, so far only data for cadmium are available. In parallel it has been checked whether changes in cellular energy allocation (CEA) could be used for the evaluation of the energetic status of an organism, but again not much experience is available so far (Gomes et al., 2015). In case this is possible, effects of chemical stressors could be determined more rapidly as in a full reproduction test.

\section{Gene Expression}

Based on a microarray (a tool that allows to detect the expression of thousands of genes at the same time) developed for $E$. albidus, Novais et al. (2012a) showed that the exposure to the organic pesticide phenmedipharm triggered a different set of genes in comparison to the exposure to the metal copper. As a consequence, the two groups of chemicals affected distinct biological functions. For instance, reproduction was only affected by pesticides, and lipid metabolic processes were only affected by metals. Moreover, three pesticides - the insecticide dimethoate, the herbicide atrazine and the fungicide carbendazim-affected biological processes in E. albidus in a dose-related manner, meaning that higher concentrations affected more transcripts than lower ones (Novais et al., 2012b). In this study, changes in gene expression, i.e., translation, regulation of the cell cycle and general response to stress, occurred after 2 days of exposure. Other studies showed that the transcriptional response was 
time-dependent (Gomes et al., 2011). Transcriptional responses to the herbicide phenmedipham were higher after 2 days compared to 4 and 21 days (Novais et al., 2012c). After 21 days, no more biological responses to pesticide exposure could be detected, perhaps because of biological processes of regulation and stress management.

Most of the studies at the gene level have been carried out with E. albidus. Another microarray is available that allows the study of the expression of targeted genes in E. crypticus in response to a stressor (Ferreira et al., 2010; Castro-Ferreira et al., 2012). Microarrays are so far the only available tools to assess pesticide effects on enchytraeids at this level of organization. However, they have the disadavantage of targeting only certain genes present on the microarray, i.e., they do not allow to screen the genome without an a priori selection of the genes that are expressed. Moreover, microarrays are biased due to signal saturation (Zhao et al., 2014). To screen the genome expression without a priori selection and to quantify the level of expression of the differentially expressed genes, toxicogenomic approaches should be used, i.e., differential transcriptome analysis. However, so far these methods have not been standardized. It seems that there is a potential of using gene expression in risk assessment (Novais et al., 2012b), especially since a database containing genomic information for E. albidus is freely available (Novais et al., 2012a).

\section{Biomarkers}

Pesticide exposure produces oxidative stress through the generation of free radicals (i.e., reactive oxygen species, ROS) and lipid peroxidation induced in the tissues of mammals and other organisms (Banerjee et al., 2001). All organisms have defense systems including non enzymatic [e.g., vitamines) and enzymatic mechanisms [e.g., production of superoxide dismutase (SOD), catalase (CAT), glutathione peroxidase (GPx), glutathione Stransferase GST] that limit the potentially damaging effects of ROS on cells. Persistent detrimental changes in cell function occur only when all of the detoxification, repair and compensation systems are exceeded. Beyond this "threshold," cellular homeostasis is no longer ensured, and short and longterm, and often irreversible, negative consequences may occur (Mercurio, 2017).

Oxidative stress represents an imbalance between the production of ROS and the body defenses. Whereas direct measurement of ROS is difficult because of extremely short half-lives (Pryor, 1991), thiobarbituric acid reactive substances (TBARS) are more accessible. TBARS are degradation byproducts of fats formed during lipid peroxidation (Howcroft et al., 2009) that can be detected by the TBARS assay using thiobarbituric acid as a reagent. The measure of TBARS thus ensures the detection of a biochemical response even if some oxidative stress responses have been missed. Regarding cellular responses of enchytraeids to pesticides, several of these biomarkers have already been studied. Novais et al. (2014) assessed the effects of dimethoate, atrazine and carbendazim on the antioxidant defenses of E. albidus at different concentrations known to affect their reproduction (i.e., EC20, EC50, and EC90) and at different timings (i.e., 2, 4, 8, 14, and 21 days). They showed oxidative stress for all tested pesticides at sub-lethal concentrations. Moreover, atrazine induced damage in lipids, measured by lipid peroxidation. Once more, the time of exposure influenced the response of enchytraeids to pesticides since effects were more pronounced after 8 days of exposure than before (i.e., 2 and 4 days). Howcroft et al. (2009) found stronger effects on biomarkers after 3 weeks than after 2 days of exposure to Betanal (i.e., formulation with $157 \mathrm{~g} / \mathrm{L}$ phenmedipham). This herbicide did not significantly alter the biomarker responses evaluated on E. albidus exposed during 2 days. However, the total glutathione and TBARSlevels increased, associated with an increase in activities of CAT, GPx, and GR and a decrease in GST activity after 3 weeks of exposure.

When neurotoxic pesticides are used, the transmission of the nervous influx can be disrupted (Howcroft et al., 2011). Cholinesterases (ChE) are a family of enzymes that catalyze the breakdown of some choline esters that act as neurotransmitters. It therefore plays a central role in the mechanism of neurotransmission. For instance, when acetylcholinesterase (AChE) activity is inhibited, the cholinergic receptors are overstimulated because of large amounts of acetylcholine accumulate in the synaptic junction. This can lead to behavioral changes and potentially to death (Howcroft et al., 2011). Similarly, gamma-aminobutyric acid (GABA) is the major inhibitory transmitter at neuromuscular synapses and synapses in the central nervous system, being also a biomarker of neurotoxic effects (Bicho et al., 2015). It has been shown that dimethoate caused ChE inhibition in E. albidus, indicating an impairment of the neuronal function, but further work is surely needed before such endpoints can be used in regulatory testing (Novais et al., 2014). Similarly, Howcroft et al. (2011) showed that a commercial formulation of phenmedipham inhibited ChE activity of E. albidus after 3 weeks of exposure, showing that ChE inhibition was a relevant biomarker for the studied pesticide.

Finally, along with the oxidative stress response, the energy reserves can provide information on the health status of the individuals. Because energy is a limiting factor for organisms, presence of pesticides can influence the trade-offs between energy allocated to stress management and life history traits, i.e., survival, growth, or reproduction. Organisms have to allocate their energy not only for maintenance, growth and reproduction but also for stress response (i.e., detoxification processes) while ensuring their basal metabolism and vital functions. Novais and Amorim (2013) studied the effects of three pesticides on cellular energy allocation (CEA) of E. albidus for up to 8 days, using concentrations analogous to the EC10, EC20, EC50, and EC90 values for these chemicals as previously determined in standard laboratory tests. A reduction in CEA was observed but only for atrazine at exposure times longer than 4 days. The authors explained that the low effects on CEA at concentrations known to affect reproduction (ECx) could indicate that the reduction in reproduction was not likely to be caused by a reduction in the total energy budget during the first 8 day of exposure. A complex endpoint such as CEA should thus always be complemented with measurements of the available energy reserves (Ea) and energy consumption (Ec). 


\section{Summary and Outlook}

Despite the scarce literature, some advice can be given to assess the effects of pesticides on enchytraeids at sub-individual levels. Considering that the molecular and biochemical responses of E. albidus to pesticides appeared to be dose-related and timedependent, it is recommended to test different concentrations of pesticides and different times of exposure. Experiment durations should be chosen to assess short, medium, and long-term responses, thus allowing to characterize gene expression and biomarker changes in a situation where reproduction occurred. Finally, this literature review makes evident a great need of further research at the sub-individual levels that addresses the effects of multiple stressors on the one hand and more ecologically relevant species of enchytraeids on the other. Moreover, although the reported references allow to infer the cascade of reactions that occurs when potworms are exposed to pesticides, few authors studied the link between different levels of biological organization (Novais et al., 2012b; Bicho et al., 2015) Finally, it is worth noting that to be able to discriminate between stress responses and natural ecological variations of biomarker expression, it is necessary to know the normal operating range (NOR) of a species. The first attempt was done by Novais and Amorim (2014) for E. albidus who provided a naturally varying ecological window for gene expression.

Within the last 10 years, interest in a mechanistic understanding on effects of chemicals in enchytraeids has increased (Spurgeon et al., 2008). Ecotoxicogenomic approaches can be used to analyze initial molecular and cellular effects, and the necessary sequence information is now available for enchytraeids, especially E. albidus. Therefore, it is now possible to address the biochemical basis of species sensitivity, the prevalence of multiple (and unexpected) modes of action, the consequences of chemical-induced change at the population and community level, and to derive a better understanding of the combined effects of pollutants (Spurgeon et al., 2008). While there is certainly an inherent (biological) variability, it seems that it will thus be possible to differentiate between the influence of test conditions and the effects of a stressor. In this context it is important to address metabolic effects of pesticides according to the outcome adverse pathway selection, by which already identified metabolic pathways of individual chemicals can be used as signal of chemical toxicity.

\section{Response at the Individual and Population Levels Test Methods}

For about 50 years, enchytraeids have been used in laboratory studies with chemicals (e.g., Weuffen, 1968) and pesticides in particular (Way and Scopes, 1968; see also Römbke and Moser, 2002). These old data are difficult to evaluate because often agar or water was used as test substrate (e.g., Römbke and Knacker, 1989; Westheide et al., 1991; Christensen and Jensen, 1995; Kristufek and Ruzicka, 1995). Compared to tests performed with soil they are less useful for the assessment of chemicals since the exposure conditions are too artificial.
From the beginning, almost exclusively species of the genus Enchytraeus were tested, using both acute and chronic endpoints (Purschke et al., 1991) as well as bioaccumulation (Rüther and Greven, 1990). Criteria such as practicability (e.g., short generation times, easy identification, simple breeding) and sensitivity were used to find the most suitable species. For example, Brüggl (1994) compared the biology of E. crypticus and E. minutus (now E. christenseni) under laboratory conditions, measuring cocoon production, number of eggs per cocoon, and population growth. Originally E. albidus was the preferred test organism due to its size (ca. $2 \mathrm{~cm}$ ), but E. crypticus became more popular due to its broader ecological range and higher practicality (e.g., shorter test duration, higher juvenile numbers, Kuperman et al., 2006). This recommendation has been confirmed several times (Castro-Ferreira et al., 2012; Voua Otomo et al., 2013). Bandow et al. (2013) proposed Enchytraeus bigeminus which reproduces asexually via fragmentation. Its handling and breeding is as easy as that of E. crypticus. In addition, several species from other genera have been proposed as test species, e.g., for forest litter the "typical" species of such habitats, Cognettia sphagnetorum-but testing this fragmenting species is difficult (Augustsson and Rundgren, 1998). Species of the genus Fridericia, being more relevant for agricultural soils, were also investigated in laboratory tests, e.g., in Korea (An and Yang, 2009) or China (Yang et al., 2012a).

For about 15 years, standardized chronic laboratory tests with enchytraeids have been available. The Enchytraeid Reproduction Test (ERT) (Table 2) was standardized in four versions, which differ only slightly: the ISO test (2004) covers retrospective sample testing from contaminated sites, the OECD test (2004) focuses on testing individual chemicals (particularly pesticides), the ASTM test (2004) has a broader approach and includes earthworms, and the ABNT test (2012) covers tropical conditions. Life duration (or the length of the full life-cycle) has been proposed as an additional endpoint more than 10 years ago (Pokarzhevskii et al., 2003). Recently Bicho et al. (2015) have demonstrated that this endpoint could be a worthwhile addition to the ERT.

Enchytraeids can avoid unfavorable environmental conditions, meaning that this behavior can be used as a quick effect endpoint: the organisms could choose between the control and a soil spiked with a pesticide. Such an enchytraeid avoidance test was developed by Achazi et al. (1999). Later on, the design of the standard earthworm avoidance test (International Organization for Standardization, 2008) was used as template, using small two-compartment test vessels. However, enchytraeids did not react more sensitively to the fungicides benomyl and carbendazim in these tests than in chronic tests (Amorim et al., 2005a). The experiments were repeated with different artificial soils (modified in terms of $\mathrm{pH}$, clay or peat content) and different durations in order to improve the test methodology. However, sensitivity remained low and results were highly variable (Amorim et al., 2005b, 2008a,b). In addition, no clear relationship between avoidance behavior and ecologically more relevant endpoints such as reproduction could be established (Novais et al., 2010). When testing mixtures of pesticides with E. albidus Loureiro et al. 
TABLE 2 | Overview of the properties of the Enchytraeid Reproduction Test (ERT), modified from Römbke and Moser (1999) and Römbke (2003).

\begin{tabular}{|c|c|}
\hline Guideline + Reference & $\begin{array}{l}\text { Guideline according to American Society for Testing and Materials (2004), International Organization for Standardization (2004), and } \\
\text { Organisation for Economic Co-operation and Development (2004) }\end{array}$ \\
\hline Test principle & Chronic, sub-lethal laboratory test \\
\hline Test parameter & Mortality (adults), reproduction (number of juveniles) \\
\hline Test duration & Range-Finding-Test: 2 weeks; main test: variable, depending on the species; $E$. albidus: 6 weeks; others species: 4 weeks \\
\hline Test species & Enchytraeus albidus (Enchytraeidae) or E. crypticus; other species of this genus; in all cases originating from mass culture \\
\hline Test substrate & $\begin{array}{l}\text { Artificial soil: quartz sand, kaolin, peat, calcium carbonate and water (Organization for Economic Co-operation and Development, } \\
\text { 1984); also field soils possible }\end{array}$ \\
\hline Application of test substance & Mixed into the artificial soil; mixtures of contaminated and control soil also possible \\
\hline Test conditions & $\begin{array}{l}10 \text { adult ( }=\text { clitellate) worms per test vessel (glass with lid; } 0.2-0.25 \mathrm{~L} \text { volume); temperature: } 20 \pm 2^{\circ} \mathrm{C} \text {; permanently no light; } \\
\text { moisture: } 40-60 \% \text { of the } \mathrm{WHC}_{\text {max., }} \text { extraction of the juveniles using Bengal red; weekly feeding with rolled oats }\end{array}$ \\
\hline Control & Untreated test substrate (e.g., artificial soil or a reference soil such as the German LUFA 2.2) \\
\hline Validity criteria (control) & Mortality < 20\% (adults); number of juveniles per test vessel (at the end of the test) $>25$ (E. albidus) or > 50 (other species) \\
\hline Test assessment & NOEC or ECx (treatment vs. control) \\
\hline Reference substance & EC50 (reproduction) of Carbendazim: $1.2 \pm 0.8 \mathrm{mg} / \mathrm{kg}$ \\
\hline Limitations and remarks & Modifications: depending on the Enchytraeus-species and, for soil quality assessment, on the test soil (e.g., LUFA 2.2) \\
\hline
\end{tabular}

(2009) found antagonisms for dimethoate and atrazine, while synergisms were detected for lindane and dimethoate.

Some years ago, enchytraeids (especially E. albidus, E. luxuriosus) were included in the oligochaete standard bioaccumulation test (Organisation for Economic Co-operation and Development, 2010; Table 3). Regularly, this test is performed with earthworms, since effect data are usually available only for them. So far, few data from enchytraeid tests have been published (e.g., Bruns et al., 2001; de Amorim et al., 2002).

\section{Effects of Insecticides}

The effects of insecticides on enchytraeids are compiled in Table S1. In total, 12 active ingredients (plus one PPP metabolite) have been studied in 31 tests. The best known examples are dimethoate and lindane, which were investigated seven and five times, respectively. The former was used as a model chemical in the EU-SECOFASE-project (Løkke and van Gestel, 1998), while both were used in two Ph.D. theses (Amorim et al., 1999; Lock and Janssen, 2002). More than half (i.e., 16) of these tests were performed with E. albidus, 11 with E. crypticus (named E. buchholzi s.l. in three of them), three with E. bigeminus and one with C. sphagnetorum. Twelve tests were performed with OECD artificial soil, seven with the standard field soil LUFA 2.2 and the remaining 12 ones covered a wide geographical and pedological range of field collected soils (including one tropical soil). Fifteen tests were performed according to the OECD guideline No. 220 and four to the ISO guideline (including one draft version). Five avoidance tests were conducted according to an ISO draft guideline. Six tests were performed before the standard guidelines were fixed. With the exception of the avoidance tests, the performance of all tests did not differ much. LC50 values were

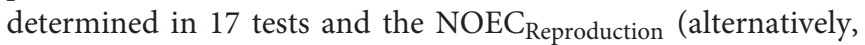
the EC10 is listed rarely) in 19 tests. Thirteen EC50 Reproduction but only five $\mathrm{EC} 50_{\text {Avoidance }}$ values were found. When several endpoints were measured, mortality and (almost always) avoidance was found to be less sensitive than reproduction.
Thus, usually the NOEC Reproduction was the most sensitive endpoint.

More contrasting results were found when looking at the effects of insecticides on enchytraeids in detail. We firstly discuss the tests in which only small effects were found [i.e., where the most sensitive endpoint is $>10 \mathrm{mg}$ a.i. (active ingredient) $/ \mathrm{kg}$ soil DW (dry weight)], followed by those with effect values $<10 \mathrm{mg}$ a.i./kg soil DW-and in particular those, which have been tested several times, often in different soils. The value of $10 \mathrm{mg}$ a.i. $/ \mathrm{kg}$ soil DW was chosen since even in worst case conditions, the exposure in the field will not exceed this concentration.

The first group consists of chlorantraniliprole (no effects on reproduction up to 1,000 $\mathrm{mg}$ a.i./kg soil DW, Lavtižar et al., 2016), chlorpyrifos (with just one EC50 Avoidance value of $933 \mathrm{mg}$ a.i. $/ \mathrm{kg}$ soil DW, Amorim et al., 2008b), toxaphene (no effects on survival and reproduction at $620 \mathrm{mg}$ a.i./kg soil DW, Bezchlebová et al., 2007), parathion and its metabolite 4-nitrophenol (all reported effect values $>20 \mathrm{mg}$ a.i./kg soil DW, Römbke, 1991; Römbke and Moser, 1999). Natal-da-Luz et al. (2012) reported that spraying the insecticide diazinon on soil samples from Costa Rica did not cause adverse effects on E. crypticus (NOEC $_{\text {Reproduction }}$ of $>16 \mathrm{mg}$ ai./kg soil DW). Testing the effects of ethoprophos on E. crypticus in a Mediterranean soil resulted in an EC50 value of $68.5 \mathrm{mg}$ a.i./kg soil DW (Leitão et al., 2014).

Alpha-cypermethrin belongs to the second group (i.e., effect values $<10 \mathrm{mg}$ a.i./kg soil DW). Both NOEC and EC50 Reproduction are below $5 \mathrm{mg}$ a.i./kg dry soil (Hartnik et al., 2008). Malathion affects the reproduction of E. albidus at concentrations between 5 and 10 a.i./kg soil DW in two field soils and OECD soil, without any relation to their soil organic matter content (4.3 and 2.3 vs. $10 \%$; Kuperman et al., 1999). This insecticide was more toxic to E. albidus juveniles than to adults in OECD soil.

In the following, some well-studied insecticides will be discussed. Puurtinen and Martikainen (1997) studied the effects of dimethoate on a small Enchytraeus species (probably E. buchholzi s.l.) in uncontaminated field soil at three different moisture levels (40, 55 and $70 \%$ of the soil WHC). It is less toxic 
TABLE 3 | Overview of the properties of the Oligochaete Bioaccumulation Test (Organisation for Economic Co-operation and Development, 2010).

\begin{tabular}{|c|c|}
\hline Guideline + Reference & $\begin{array}{l}\text { Guideline according to Organisation for Economic Co-operation and Development (2010; see also American Society for Testing and } \\
\text { Materials, 2004) }\end{array}$ \\
\hline Test principle & Bioaccumulation test under laboratory conditions \\
\hline Test parameter & Accumulation and elimination of chemicals \\
\hline Test duration & 14 days each for the accumulation and the elimination phase \\
\hline Test species & Enchytraeus albidus or E. luxuriosus: E. crypticus also possible \\
\hline Test substrate & $\begin{array}{l}\text { Artificial soil: quartz sand, kaolin, peat, calcium carbonate and water (Organization for Economic Co-operation and Development, } \\
\text { 1984); also field soils such as LUFA } 2.2 \text { possible }\end{array}$ \\
\hline Application of test substance & $\begin{array}{l}\text { Mixed into the test substrate; mixtures of contaminated and control soil also possible (use of radio-labeled substances highly } \\
\text { recommended) }\end{array}$ \\
\hline Test conditions & $\begin{array}{l}10 \text { adult (= clitellate) worms (e.g., } 5-10 \mathrm{mg} \text { wet weight per individual E. albidus and a length of about } 1 \mathrm{~cm}) \text { per test vessel (glass with } \\
\text { lid; } 10-20 \mathrm{~g} \text { d.w. at a soil layer of } 2-3 \mathrm{~cm} \text { ); temperature: } 20 \pm 2{ }^{\circ} \mathrm{C} \text {; permanently no light; moisture: } 40-60 \% \text { of the WHC } \mathrm{max} ., \mathrm{manual} \\
\text { extraction of the worms }\end{array}$ \\
\hline Control & Untreated test substrate (e.g., artificial soil or a reference soil such as the German LUFA 2.2) \\
\hline Validity criteria (control) & Mortality $<20 \%$ (adults) of the total number of the introduced worms at the end of the test \\
\hline Test assessment & Bioaccumulation factor: BAF or BSAF (lipid-normalized) \\
\hline Limitations and remarks & Limited experience available so far (mainly from an international ring-test; Bruns et al., 2001) \\
\hline
\end{tabular}

in dry soil than in moist soil. Martikainen (1996) used the same study design, species and test chemical to investigate the effects of three soils with different texture. High soil organic matter content reduced the toxic effects. This insecticide showed low toxicity for E. buchholzi s.l. A similar result was found in two avoidance tests with E. albidus: the $\mathrm{EC} 50_{\text {Avoidance }}$ values were $58.3 \mathrm{mg}$ a.i. $/ \mathrm{kg}$ soil DW (Amorim et al., 2008b) and $34 \mathrm{mg}$ a.i./kg soil DW (Loureiro et al., 2009), respectively. Finally, low toxicity of dimethoate was also determined in a test with C. sphagnetorum (Løkke and van Gestel, 1998).

The insecticide lindane has been tested often, especially during the development of the ERT. Early work, e.g., that of Dormidontova (1973) could not be used since almost no information on test conditions or results is available. Loureiro et al. (2009) tested the toxicity of lindane on the mortality and avoidance behavior of E. albidus in LUFA 2.2 soil and found that the effects occurred in a similar range. Using OECD artificial soil, an LC50 of about $200 \mathrm{mg}$ a.i./kg soil DW and a $\mathrm{NOEC}_{\text {Reproduction }}$ of about $20 \mathrm{mg}$ a.i. $/ \mathrm{kg}$ soil DW were found (Amorim et al., 1999). Depending on the soil type, Lock et al. (2002) found almost the same result (EC50 Avoidance $172.5 \mathrm{mg}$ a.i./kg soil DW) with E. albidus in OECD soil. Another example is the effect of lambda-cyhalothrin on the reproduction of the fragmenting species E. bigeminus which was examined under three different soil moisture levels $(30,50$, and $70 \%$ of the soil WHC) (Bandow et al., 2013). A higher toxicity was observed in soil with lower moisture level. For lambda-cyhalothrin, the 21day EC50Reproduction values at the three levels of soil moisture were calculated to be $1.33,3.79$, and $4.75 \mathrm{mg}$ as $/ \mathrm{kg}$ soil DW, respectively.

Finally, Chelinho et al. (2012) studied the effects of the insecticide/nematicide carbofuran on E. crypticus under tropical conditions in the laboratory, following basically the ISO standard (International Organization for Standardization, 2004). Actually, a new application method was used, intended to simulate pesticide spraying. The recommended dose of the fungicide carbofuran $(1.178 \mathrm{mg} / \mathrm{kg}$ soil DW), twice the recommended dose, and a water control were sprayed on plastic trays (1.10 $\times 0.49 \times 0.17 \mathrm{~m}$ length width $\times$ depth) containing a loamy soil. An EC50 value of $0.739 \mathrm{mg}$ a.i./ $\mathrm{kg}$ soil DW was determined for reproduction, i.e., lower than the predicted environmental concentration (PEC) after the recommended use of this pesticide. Chelinho et al. (2012) repeated the study with carbofuran and $E$. crypticus but this time they used soil which was applied in the field on plots varying in size between $3 \times 1$ and $4 \times 2 \mathrm{~m}$. About $18 \mathrm{~h}$ after spraying, the soil was collected for enchytraeid tests to be performed similarly as in the previous test. An EC50 value of $0.750 \mathrm{mg} / \mathrm{kg}$ soil DW was determined for the reproduction of E. crypticus, again a risk for potworms could not be excluded. In both tests no enchytraeid mortality was observed.

\section{Effects of Fungicides}

The effects of fungicides on enchytraeids are compiled in Table S2. Only six active ingredients have been studied in 32 tests so far. Twenty-two tests were performed with E. albidus, three with both E. crypticus and E. bigeminus as well as two with E. coronatus. Fridericia ratzeli-a species not cultured but collected from a grassland near Frankfurt-and E. buchholzi were used once. Fifteen and seven tests were conducted with OECD artificial soil or with the standard field soil LUFA 2.2, respectively. Two times LUFA 2.1 and 2.3 soils were used in the early days of the ERT development. Four field soils with varying properties and two forest soils (without and with $\mathrm{pH}$ modification $(\mathrm{pH}$ $=4.5$ and 6.0, respectively) were used in order to evaluate the influence of soil acidity. Nineteen tests were performed according to the ISO guideline 16387, three avoidance tests were tested according to the respective ISO draft and three tests followed the OECD guideline. In seven tests performed during the ERT development no guideline was used. With the exception of the avoidance test, results of these tests were similar, as long as the same soil was used. LC50 values were determined in 17 tests and the $\mathrm{NOEC}_{\text {Reproduction }}$ in eight tests. Nine EC50 Reproduction and six EC50 Avoidance values were found. 
Azoxystrobin and chlorothalonil were tested just once. Pyrimethanil was studied in three tests, differing only in their soil moisture. The remaining tests were run with pentachlorophenol (PCP) and benomyl (both seven times) and carbendazim (14 times). In the laboratory tests listed in Table S2, PCP was not very toxic to E. albidus (the LC50 values are in a range of 15.5$444 \mathrm{mg}$ a.i./kg soil DW). Mortality is clearly correlated with soil properties, especially with organic matter content, sand and $\mathrm{pH}$.

The high toxicity of benomyl and in particular carbendazim to earthworms has been known for a long time (Stringer and Wright, 1973). Thus, it is used as reference substance in earthworm field tests (International Organization for Standardization, 1998, 1999) and was also selected as a model chemical during the development of the ERT (Römbke and Moser, 1999, 2002). Especially in the international ringtest, a huge data set was compiled (92 tests in total), allowing to assess the variability of this test system (Weyers et al., 2002). Variations were caused by a mixture of factors such as inherent biological variability or the level of experience of the participants. However, the ERT results were robust enough to standardize this method-a view which was supported by the first review on the effects of chemicals on enchytraeids (Didden and Römbke, 2001). Based on these experiences, carbendazim was selected as reference substance for the ERT (Römbke and Moser, 2002). One example from the ERT ringtest shows the effects of carbendazim on the reproduction of $E$. albidus, indicating that the numbers of juveniles per laboratory were close to the overall mean and that the EC10 values were almost always lower than the NOECs (see Figure 1; Römbke, 2003).

A clear difference in sensitivity between acute and chronic endpoints was found for carbendazim: the acute tests resulted in an LC50 of $>10 \mathrm{mg} / \mathrm{kg}$ soil DW while the EC50 in the chronic test was $2.8-3.7 \mathrm{mg} / \mathrm{kg}$ soil DW. No significant differences were found between test runs following a NOEC design or those performed according to an ECx design, but the latter were less variable. The outcome of this ringtest formed the basis for the OECD, ISO, ASTM, and ABNT guidelines. The high chronic toxicity of carbendazim to enchytraeids has been confirmed several times (e.g., Castro-Ferreira et al., 2012). Avoidance behavior is not more sensitive than reproduction or even mortality (Amorim et al., 2005a). However, when spiking carbendazim in LUFA 2.2 soil and aging it for one, 14 or 28 days before starting the tests, Kobetičová et al. (2009) could show in an avoidance test that $E$. albidus clearly preferred the soil which was aged for 28 days, i.e., that one with the lowest availability of carbendazim.

Arrate et al. (2002) performed also the ERT with carbendazim, but they used E. coronatus instead of E. albidus-and tested the same compound in parallel in agar. Reduction in the number of juveniles was best explained by reduced hatching from cocoons, leading to a better understanding of the causes of toxic effects on these worms. In addition, the authors could show that the Mode-of-Action (MoA) of carbendazim significantly differs from those determined for other chemicals. Finally, it could be shown that the effects of this fungicide on E. albidus in laboratory tests differed in LUFA 2.2 soil in the absence or presence of $15 \% \mathrm{NaCl}_{2}$ (Silva et al., 2015).

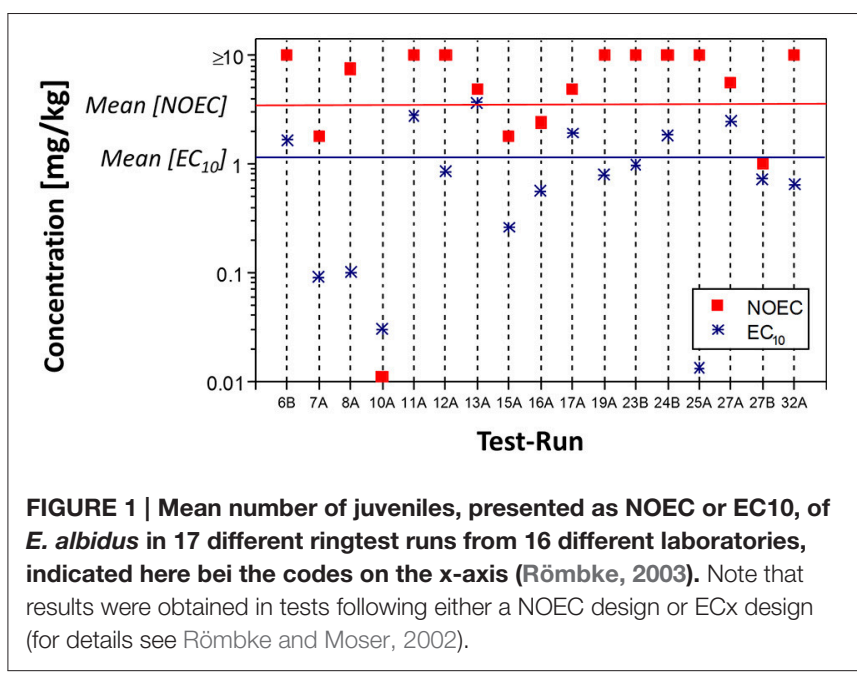

Finally, Chelinho et al. (2014) investigated the effects of carbendazim on the reproduction and avoidance behavior of $E$. crypticus in five to eight Mediterranean soils plus OECD soil. The

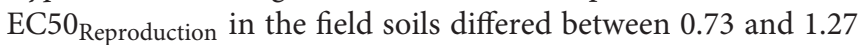
(OECD: 0.89) $\mathrm{mg}$ a.i./kg soil DW, while in the avoidance tests less effects were determined [1.3-9.4 (OECD: 3.9) $\mathrm{mg}$ a.i./kg soil DW]. In both tests there was no difference between the effect size in OECD soil compared to the field soils.

Puurtinen and Martikainen (1997) studied the effects of benomyl on Enchytraeus buchholzi s.l. in uncontaminated field soil at three different moisture levels (40, 55, and 70\% of the soil water holding capacity, WHC). The toxicity of benomyl decreased with increasing soil moisture content, but the mechanisms behind this behavior were not clearly understood. In a parallel study, Martikainen (1996) assumed that the high organic matter content of the soil reduced the toxic effects of this pesticide.

The fungicides azoxystrobin and chlorothalonil were tested in the ERT, using E. crypticus, but with a Mediterranean agricultural soil (Leitão et al., 2014). Effects were only observed at high concentrations (ca. 500-1,000 mg a.i./kg soil DW).

Finally, in enchytraeid reproduction tests with the fragmenting species E. bigeminus, pyrimethanil was examined under three different soil moisture levels (30,50, and $70 \%$ of the soil WHC; Bandow et al., 2013). The highest toxicity was observed in soil with the lowest moisture level (i.e., EC50 of 435, 499 , and $829 \mathrm{mg}$ a.i./kg soil DW), probably due to synergistic effects of both the fungicide and moisture conditions.

\section{Effects of Herbicides}

The effects of herbicides on enchytraeids are compiled in Table S3. Only four active ingredients were tested in 23 tests so far. Bromoxynil was tested once, atrazine twice, and 2,45 -T (banned already 20 years ago because of its carcinogenic properties) four times. All the other 16 tests were performed with phenmedipham, mainly as part of a Ph.D. thesis (Amorim et al., 2005a,b, 2008b). Out of these 23 tests, 17 were performed with E. albidus, five with E. luxuriosus and one with Fridericia 
bulbosa (an invalid name according to Schmelz, 2003). The lack of tests with E. crypticus indicates that-with two exceptionsmost of these tests were performed at least 10 years ago. OECD and LUFA 2.2 soils were used in five and eight tests, respectively. Eight tests were performed with, in total, three field soils. In the remaining test the very sandy LUFA standard soil 2.1 and the slightly humus-richer LUFA standard soil 2.3 were used. Eleven tests were performed according to the ISO guideline 16387, seven avoidance tests were tested according to the respective ISO draft and only one test followed the OECD guideline. In four tests no guideline was used, but they were conducted already in 1988/1989 (Römbke, 1989). LC50 values were determined in 14 tests and the EC50 Reproduction values in 12 tests. Four EC50 Avoidance values were found.

The low number of herbicides tests is probably caused by the fact that, due to their MoA, low effects on enchytraeids are expected. This expectation is fulfilled in the case of 2,4,5trichlorophenoxyacetic acid (2,4,5-T) for which an extremely high LC50 value of $14,150 \mathrm{mg}$ a.i./ $\mathrm{kg}$ soil DW was found in OECD soil (Römbke, 1989). In the three LUFA soils, the LC50 values were by a factor of more than 10 lower. In contrast, atrazine affected the reproduction of E. albidus already at low concentrations (1-2 mg a.i./kg soil DW), independently from the endpoint (NOEC or EC50). Interestingly, avoidance behavior (EC50: $38 \mathrm{mg}$ a.i./kg soil DW) was found to be an even less sensitive endpoint than mortality (LC50: $12 \mathrm{mg}$ a.i./kg soil DW) (Novais et al., 2010).

Bromoxynil was found to cause quite high mortality of Fridericia bulbosa, even at low concentrations (Yang et al., 2012 b). Thus, the authors recommended mortality as "valuable and sensitive" endpoint. This view is not supported by the many studies where reproduction and (sometimes) avoidance is more sensitive than mortality.

Phenmedipham is by far the best studied herbicide (16 tests), covering two species, three endpoints and five soils. Differences in sensitivity between species were low (i.e., within a factor of two in the same soils). There is an influence of soil properties on toxicity: LC50 values in OECD soil were by a factor of two higher than in LUFA 2.2. soil. Results from other field soils are somewhere in between, i.e., there is no clear difference to tests in OECD soil. Mortality and reproduction do not always show the same tendency: in tests with the field soil "Coi3" $E$. luxuriosus shows almost the same LC50 as in OECD soil, but the EC50 Reproduction differs by almost a factor of 30 (E. luxuriosus reacts much stronger than E. albidus). Surprising differences were also found when performing avoidance tests in different soils but always with E. albidus: the EC50 Avoidance varied between $<1$ and $252 \mathrm{mg}$ a.i./kg soil DW. This difference might be caused by a combination of different soil properties but also by a lack of experience and/or the higher variability of the results of enchytraeid avoidance tests in general.

In one of the rare tests using soils from the Mediterranean region, Chelinho et al. (2014) investigated the effects of phenmedipham on E. crypticus, in 12 soils from Spain, Italy and Portugal plus OECD soil. Both the ERT as well as the enchytraeid avoidance test were used. The EC50 Reproduction in the field soils differed between 3.8 and $32.8 \mathrm{mg}$ a.i./kg soil DW.
In contrast, the $\mathrm{EC} 50_{\text {Avoidance }}$ could only be determined in seven field soils, showing in general less toxicity (range: 19.1$>81 \mathrm{mg}$ a.i./kg soil DW). Interestingly, the effects in OECD soil in the reproduction tests were almost always lower than in the field soils (EC50 Reproduction: $29.2 \mathrm{mg}$ a.i./kg soil DW), while the opposite was determined in the avoidance tests with OECD soil: EC50 ${ }_{\text {Avoidance }}: 14.1 \mathrm{mg}$ a.i. $/ \mathrm{kg}$ soil DW). No significant relationships between soil properties and toxicity were found. Probably the range of properties of the selected field soils was too narrow to identify clearly their influence on toxicity.

Scoriza et al. (2015) studied the effects of the herbicide mesotrione which is used in forest restoration in Southern Brazil. Methodically, a combination of field experiments, focusing on soil arthropods, and laboratory tests with E. crypticus was used. Composite samples taken from the field before and one, eight and 22 days after application of 0.4 . L/ha mesotrione were studied. Enchytraeid reproduction was severely affected in all samples after application. Thus, the authors recommend to use other herbicides (e.g., Fluazifop-P-butyl or Nicosulfuron), since these compounds did not affect enchytraeid reproduction. Since this herbicide was used in forests, it is not listed in Table S3.

\section{Bioaccumulation of Pesticides in Enchytraeids}

The best example for the use of enchytraeids (E. albidus, E. luxuriosus) in the standard OECD bioaccumulation test (Organisation for Economic Co-operation and Development, 2010) is a study performed with the insecticide lindane, which is, at least in Europe, no longer registered (Bruns et al., 2001; de Amorim et al., 2002). Lindane was quickly accumulated in both species in both soils, but was also quickly eliminated after transfer of the worms into clean soil (Figure 2). The experiment was repeated with both soils but only with $E$. albidus 1 and 2 months after spiking, i.e., the aging of this insecticide did reduce the bioaccumulation in the enchytraeids. Bioaccumulation factors differed between the two soils, probably because of the lower organic matter content in the latter, natural soil: the BAF was 12.1 in OECD soil and 22.0 (E. albidus)/36.1 (E. luxuriosus) in LUFA St. 2.2 soil. This difference in the bioaccumulation factors (BAF) of lindane in the two species is probably due to size-related differences and the respective volume: surface ratio (E. albidus is larger than E. luxuriosus; Amorim et al., 2002).

\section{Summary}

First of all, a standard test method (ERT) is available, which has been used in dozens of tests in various laboratories without any difficulties. The ERT allows some flexibility, i.e., various species of the genus Enchytraeus as well as different soils and endpoints can be used. The experiences with enchytraeid laboratory tests can be summarized as follows:

- Testing started with the large species E. albidus, but today it is used mainly when addressing other endpoints than those required in the standard tests. In "regular" standard tests, $E$. crypticus is used more often due to reasons of practicability. Differences in sensitivity could not be identified so far. Other Enchytraeus species (or species from other genera) cannot be 


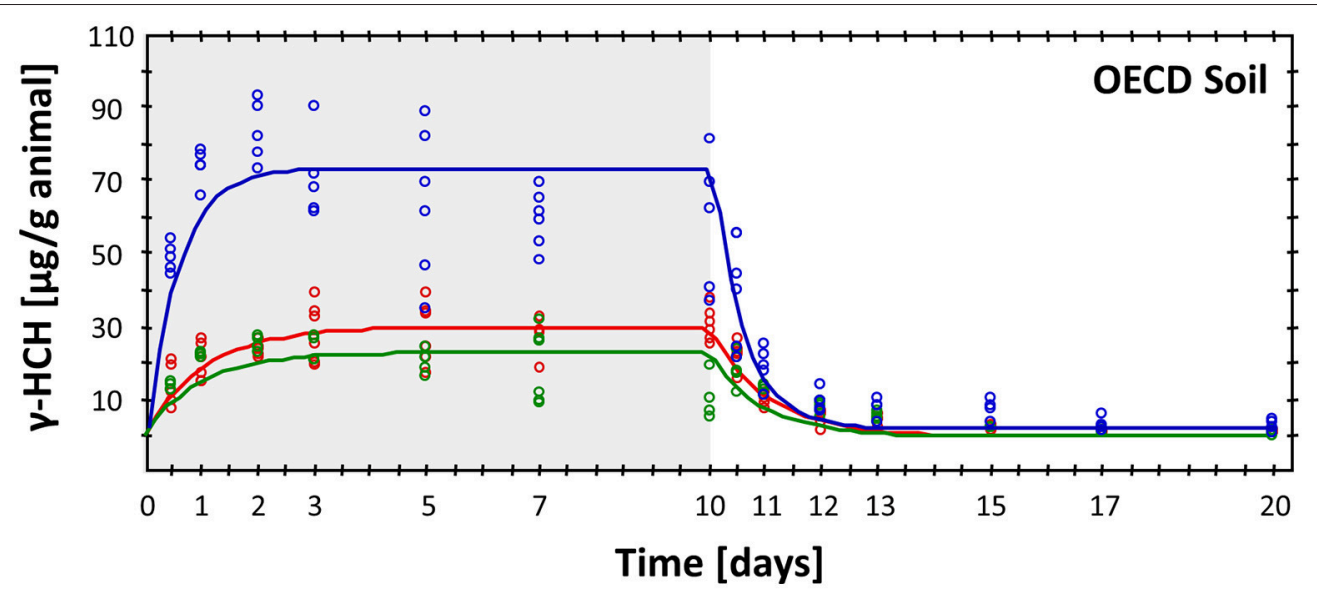

FIGURE 2 | Result of a bioaccumulation test of the insecticide lindane in Enchytraeus crypticus in OECD soil, showing both uptake (gray-shaded) and elimination phase (for details see de Amorim et al., 2002). Blue line, after freshly spiking; red line, 1 month after spiking and green line: two months after spiking.

recommended for the moment due to the low number of data available.

- When comparing endpoints, reproduction is by far the most robust and sensitive one. In contrast, the avoidance test is less useful, because of low sensitivity and high variability. Other endpoints scannot be judged due to low level of experience.

- Only few pesticides have been studied intensively, mainly the fungicide carbendazim, the insecticide dimethoate and the herbicide phenmedipharm. Most test data refer to pesticides which have been banned for years (e.g., PCP), while very few data are available for "modern" pesticides.

- The influence of soil properties on the effects of pesticides on enchytraeids is relatively well-studied, at least regarding texture and organic matter. Out of the 87 tests presented here, 31 tests were performed with OECD soil and 20 with LUFA 2.2 soil. The remaining 36 tests cover a wide range of soils from temperate regions-plus few examples from the Mediterranean and the tropics.

- An Enchytraeid Bioaccumulation Test has been standardized by the OECD some years ago, but despite its advantages in comparison to earthworms (shorter duration, smaller size and thus need of less space) it has rarely been used.

\section{Response at Community Level Methods Available}

Various types of semi-field methods have been applied in the last 50 years to measure the effects of pesticides on enchytraeids, starting with microcosms. These are small vessels filled with field soil (rarely including plants), kept in the laboratory under controlled conditions. When all components of such a microcosm (including organisms) are selected by the experimenter, they are called gnotobiotic systems (gnotos (gr.) = known) (Mothes-Wagner et al., 1992; Born, 1993; Morgan and Knacker, 1994; Scott-Fordsmand et al., 2008; Schaeffer et al., 2010). The earliest known example is a study in Azalea cultures with various stressors, e.g., the herbicide DBCP (e.g., Heungens, 1968). Some early tests are known from Japan (Kitazawa and
Kitazawa, 1980), which already studied combinations of (and thus interactions between) pesticides and ecological factors such as food addition. With few exceptions enchytraeid species were not identified. Most of the pesticides tested have been banned for a long time (e.g., pentachlorophenol, 2,4,5-T, aldicarb), while others such as carbendazim are still used today. Such microcosms are suitable for specific questions, e.g., the influence of pesticides on combinations of standard test soil invertebrates (E. crypticus, together with some springtail species and a predatory mite), but so far no standard guideline is available (Jensen and ScottFordsmand, 2012).

\section{Gnotobiotic Approaches}

Martikainen et al. (1998) were the first to study the effects of an insecticide (dimethoate) and a fungicide (benomyl), used alone or as mixture, in microcosms containing agricultural soil and indigenous soil fauna. They reported no effects on the total number of enchytraeids, but highlighted the added value of microcosm experiments in contrast to laboratory tests when studying complex questions.

The effects of carbendazim were also studied in a gnotobiotic microcosm, i.e., a plastic tube filled with sieved soil from the same site as the one used for the studies described below with Terrestrial Model Ecosystems (TME) (Burrows and Edwards, 2004). Enchytraeids (as well as other organisms) were added, exposed to the same concentrations of carbendazim and studied in the same way as in the TMEs. However, enchytraeids were not affected, meaning that this test system was-at least for this endpoint-not able to predict effects which were found both in the TMEs and in the field. A similar approach has later been used by Jensen and Scott-Fordsmand (2012) who designed a soil multi-species (SMS) test system consisting of one potworm species (E. crypticus), four springtail species and one predatory mite species. With an additional stress factor (here: the predatory mite), the springtails reacted much more sensitively to the insecticide ivermectin (primarily known as a veterinary pharmaceutical) than when exposed alone. Since the mites fed 
selectively more on enchytraeids than on springtails it is likely but not yet proven that the same phemomenon could happen with potworms.

Sechi et al. (2014) used the same SMS to study the effects of the insecticide alpha-cypermethrin on the same artificial community as described above (including E. crypticus). A community EC50 of $1.26 \mathrm{mg} / \mathrm{kg}$ soil DW was determined-a value which is significantly lower as the EC50 value measured in a single-species test with the same enchytraeid $(4.91 \mathrm{mg} / \mathrm{kg}$ soil DW) (Hartnik et al., 2008).

\section{Terrestrial Model Ecosystems (TME)}

The best-known example for a "real" semi-field method uses Terrestrial Model Ecosystems (TMEs) (Knacker et al., 2004; Förster et al., 2006; Moser and Römbke, 2007; Moser et al., 2007; Scholz-Starke et al., 2013; Bandow et al., 2016), which was originally called a "terrestrial soil-core microcosm test" (American Society for Testing and Materials, 1993). TMEs are non-disturbed soil cores (diameter 15-45 cm; height 30-60 cm), taken from the field and containing the original soil organism community except, to a certain degree, the macrofauna, especially those species living on or close to the soil surface. TME studies can be performed both in-house, e.g., in temperature-controlled rooms (Figure 3A) as well as out-doors (Figure 3B). A proposal for an OECD test guideline is available (Schaeffer et al., 2010).

In the first TME study with pesticides, Römbke et al. (1994) studied the effects of the insecticide parathion and the herbicide formulation Ustinex (consisting of two active ingredients, amitrole and diuron) on the enchytraeid community of a Central German grassland. Both pesticides were sprayed in two concentrations on top of the intact soil cores. Samples were taken 1 month before application and 1,2, 3, and 4 months after application. Enchytraeid species number and total abundance were not negatively affected, except in the treatment with the higher parathion concentration. In fact, in the TMEs with the low herbicide concentration their numbers actually increased; maybe because the insecticide eliminated Collembola (food competitors) and predatory mites (main predator).

Similarly, Moser et al. (2007) used intact soil columns collected from three grasslands in Germany, Great Britain and The Netherlands and one arable site in Portugal. They applied six different concentrations of the fungicide carbendazim as formulation Derosal ${ }^{\circledR}$. At all sites, the genus Fridericia was most negatively affected by the pesticide, mainly 8 and 16 weeks after the application, followed by species of the genus Henlea. Many Achaeta and Enchytraeus species did not decrease or even partly increased (Figure 4A). In general, enchytraeids were not affected by the two lower concentrations (in fact their number increased slightly above control level) but showed a strong decline in the TMEs treated with the two higher concentrations. During the testing period, no indication of recovery could be seen.

At the Flörsheim site, a different effect pattern was found (Figure 4B), meaning that the lowest concentration caused only small and not lasting effects. In the three higher concentrations, the effects were stronger until week eight after application. With the exception of the two highest concentrations, the control level was reached within the study duration. The differences between the enchytraeid effect patterns at the different test sites are probably mainly caused by differences in soil properties. In addition, the different species composition of the enchytraeid communities might have played a role.

The authors explained that these results could be attributed "to the different ecological requirements [...] of the different genera." For example, Fridericia and Henlea species are Kstrategists (i.e., long life duration, slow reproduction) whereas Enchytraeus species are r-strategists (i.e., short life duration, rapid reproduction) (Graefe and Schmelz, 1999). This ecological difference may affect recovery of the different species as well. In any case, the low abundance of enchytraeids belonging to the genus Fridericia would indicate a risk of high application rates of carbendazim when using the EU requirements relevant at that time (Weyers et al., 2004). Interestingly, the effects of carbendazim on the total abundance of enchytraeids were correlated with those found when measuring organic matter decomposition (using the filter-paper method) but not with those on the feeding rate as measured in the bait-lamina test (Förster et al., 2004).

Scholz-Starke et al. (2013) found 17 enchytraeid species in 45 TMEs they had collected at a German meadow site. Enchytraeids were sampled after 1, 26, and 149 days after lindane applications. The authors found no significant effects of the pesticide at concentrations ranging from 0.032 to $3.2 \mathrm{mg} / \mathrm{kg}$ soil DW on total abundance or that of individual species. Finally, Bandow et al. (2016) found that the fungicide pyrimethanil did not affect the community composition (consisting of Enchytraeus buchholzi, E. bulbosus, E. dichaetus, Fridericia bulboides, F. pretoriana, F. tuberosa, and another Fridericia species) in a TME experiment performed in Portugal, but they reported negative effects from a similar experiment performed in Germany. In the latter one, the strongest effects were found in dry soil, particularly for Fridericia connata after 8 weeks of exposure. It is not clear whether different community composition or soil properties may have caused the different outcome.

\section{Field Approach}

In order to survey enchytraeids in the field, soil samples are taken with a corer (diameter usually between 5 and $7.5 \mathrm{~cm}$ ). Theses samples are separately placed onto sieves hanging in plastic bowls filled with water, and the enchytraeids are driven via wet-extraction from the soil. This procedure has been internationally standardized (International Organization for Standardization, 2007). Species identification is only possible with living specimens, which limits the number of samples that can be handled in parallel. Species determination via genetic methods (DNA barcoding and meta-barcoding) is a promising alternative (Orgiazzi et al., 2015) since the establishment of DNA sequencing as a cheap routine laboratory procedure. However, there is still a problem with the interpretation of the results, because the number of reliable data sets combining genetic and morphological information is small.

The first field study covering the effects of pesticides on enchytraeids, among others, was performed in Northern Germany (Weber, 1953). Edwards et al. (1968) and Edwards and Lofty (1971) described effects of insecticides (i.e., 

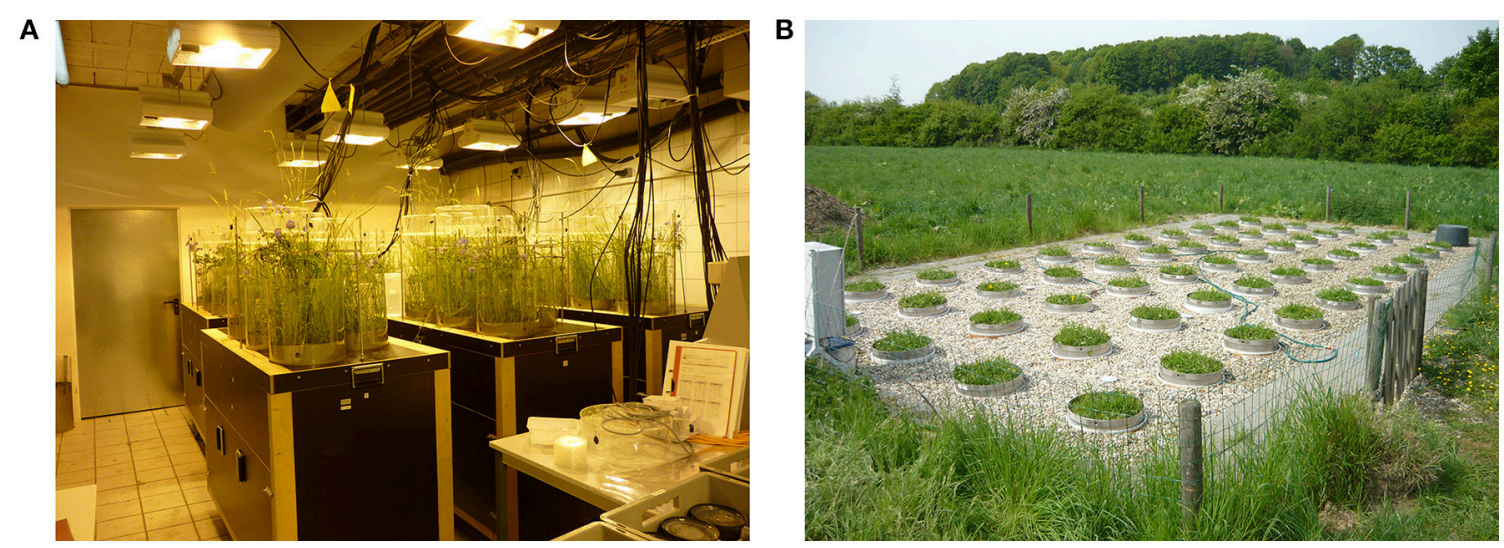

FIGURE 3 | (A) TME in-house facility (ECT GmbH) (B. Förster). (B) TME outdoor facility (RWTH Aachen/gaiac) (B. Scholz-Starke).
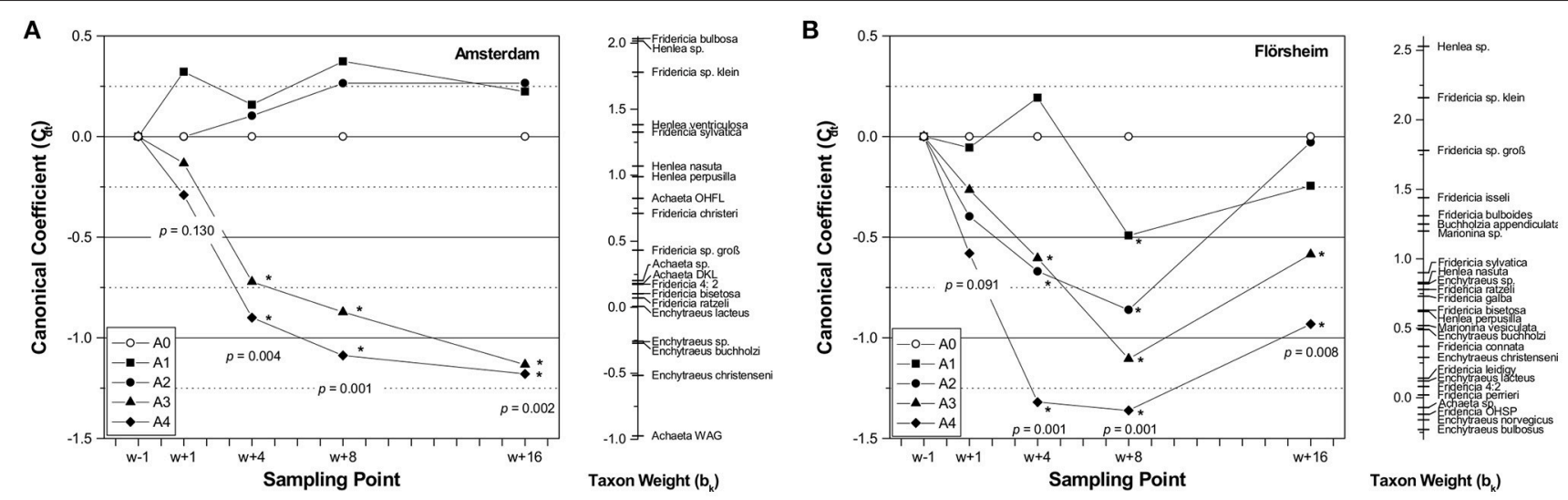

FIGURE 4 | (A) PRC (Principal Response Curve) for the effects of carbendazim on the Enchytraeid species community in the TME test of Amsterdam. Presented is the canonical coefficient (Cdt) of the different application rates at the sampling points $w+1, w+4, w+8$, und $w+16$ (weeks after application) and the taxon weight (bk) for all taxa. For each sampling point the $p$-value (Monte Carlo permutation test; 999 permutations) for the comparison of all application rates (including control) is given. Significant differences of the PCA sample scores compared to the control are indicated with an asterisk (Williams $t$-test; 2-sided, $p \leq 0.05$ ). Application rates: $\mathrm{A} 0=$ control, $\mathrm{A} 1=0.36, \mathrm{~A} 2=2.16, \mathrm{~A} 3=12.96, \mathrm{~A} 4=77.76 \mathrm{~kg}$ carbendazim $/ \mathrm{ha}$ ) For further details see Moser et al. (2007). (B) PRC (Principal Response Curve) for the effects of carbendazim on the Enchytraeid species community in the TME test of Flörsheim. For further explanations see the legend of (A).

chlorfenvinphos) or nematicides (i.e., methomyl, dazomet or aldicarb) on enchytraeids at agricultural sites. Voronova (1968) studied the effects of the insecticide Sevin on enchytraeids in the Taiga region of Russia. Since hand-sorting was used as extraction method the results of these studies are not reliable. However, Van den Brande and Heungens (1969) used already wet extraction when studying the effects of the nematocide disinfectant DD on enchytraeids in plots with Begonia. However, the outcome is hardly useful since samples were not replicated. Martin (1975) found no effect of the pesticide fenithrothion on enchytraeid abundance in a New Zealand pasture at field-relevant concentrations. The same result was reported by McColl (1984) when studying benomyl (18.6 $\mathrm{kg}$ a.i./ha) and phenamiphos (18.6 kg a.i./ha) on grasslands in New Zealand. In contrast, Popovici et al. (1977) studied the effects of atrazine at two concentrations (5 and $8 \mathrm{~kg} / \mathrm{ha}$ ) on enchytraeids-among other soil organisms -, and observed a quick decrease in enchytraeid numbers at both concentrations 1 month after application. However, numbers increased 4 months after application at the lower concentration. In a study using small field plots, Römbke et al. (1994) applied an insecticide (parathion) or a herbicide mixture (Amitrole/Diuron) at the highest recommended application rate or a 5-fold higher concentration rate. A strong increase in enchytraeid abundance and biomass occurred at the lower herbicide rate, but the high rate caused a decrease of $50 \%$ for both endpoints. Both application rates of the insecticide did not affect enchytraeid abundance or biomass. However, so far no standardized field test method is available (e.g., Römbke et al., 2009).

Enchytraeids may also avoid chemicals by vertical migration, which has been observed in a field study in a German grassland (Römbke and Federschmidt, 1995). Carbendazim was sprayed on small plots at two concentrations and the abundance, biomass and diversity of the enchytraeid community was studied for two 
years, divided into an application phase and a recovery phase. Negative reactions on the enchytraeid community were found at concentrations lower than those identified in the laboratory. However, since soil properties were not the same in the laboratory and field tests the results are difficult to compare.

The effects of the fungicide carbendazim (i.e., the formulation Derosal ${ }^{\circledR}$ ) on enchytraeids were not only determined in TME tests (Knacker et al., 2004), but also in parallel in the field, using the same concentrations (Moser et al., 2004). This work was done by different partners at one arable site (Coimbra, Portugal) and three grassland sites: Amsterdam (The Netherlands), Bangor (Wales, England), and Flörsheim (Germany). No differences regarding enchytraeid total abundance or number of species were found between the respective TMEs and field sites in the controls. Effects of carbendazim were most pronounced when looking at the abundance of worms of the genus Fridericia (especially 8 and 16 weeks after application), while the abundance of the genera Achaeta and Enchytraeus was not affected. The observed effects did not differ between TME tests and the respective field validation studies (Weyers et al., 2004). Due to high variability of data in both tests, NOEC-values could often not be determined. The EC50-values (based on total abundance) derived from the TME tests and the field validation study indicate that the reproducibility (i.e., the variation between the partners) of the EC50-values was reasonable, although different soils were used at the different sites. The EC50-values, based on total abundance, ranged between 0.7 and $37.8 \mathrm{mg}$ a.i./ $\mathrm{kg}$, which is very similar to those values based on the abundance of the most abundant genus Fridericia (i.e., 0.9-24.7 mg a.i./kg soil DW). On the contrary, the EC50-values based on the endpoint number of species was less sensitive (9.5-116.2 $\mathrm{mg}$ a.i./kg soil DW). Since no genus was consistently more sensitive than the other genera, it is recommended to include the species level in the assessment of field studies. As in the TME study performed by the same authors, effects on enchytraeids at the four field sites were not correlated with those found in the bait-lamina test but with those from organic matter decomposition tests (Förster et al., 2004).

Potworms have been recommended repeatedly for monitoring programs or assessment schemes, e.g., in the context of postregistration monitoring of pesticides (Schouten et al., 1999; Barth et al., 2000; Jänsch et al., 2005; Bispo et al., 2009). Proposals are available for reference values (diversity, species number, or abundance) of enchytraeids at different sites in the Netherlands and Germany (Rutgers et al., 2008; Beylich and Graefe, 2009).

\section{Recovery}

Recovery of enchytraeids in agro-ecosystems after pesticide exposure has not been studied so far (Kattwinkel et al., 2015). All available information is from forest sites. In a beech forest in Southern Germany, two model pesticides, the fungicide PCP and the herbicide 2,4,5-T were applied bimonthly on small field plots $\left(25 \mathrm{~m}^{2}\right)$ for about 2 years (Römbke, 2001). This study aimed to understand recovery processes after strong stress. Since very high concentrations of these pesticides were used, the enchytraeid populations were strongly affected (especially in a year with a long period of drought) during the application period (Römbke, 1988). After stopping the applications of PCP, enchytraeid abundance started to recover less than half a year later in plots with the lower application rate, while abundance remained significantly lower at the higher application rate for about at least one more year. Thus, it could be shown that such recovery depends strongly on pesticide exposure (here given as applied amount) in interaction with general (mainly climatic) factors (Figure 5) - a scheme which probably is true also for agroecosystems. As a side effect, enchytraeid abundance increased to numbers even higher than in the controls, probably because during the application period the litter layer (i.e., food) was not degraded. This picture is mainly caused by r-strategists (i.e., those adapting quickly to changing environments) such as Cognettia sphagnetorum-a potworm which can reproduce by fragmentation (Nielsen and Christensen, 1959). The recovery pattern on the plots treated with 2,4,5-T was very similar.

\section{Summary and Outlook}

In 1999, Cortet et al. (1999) firstly summarized the experiences with PPP effects on enchytraeids, listing five papers. Two years later, Didden and Römbke (2001) summarized the information provided in about 30 papers and identified issues deserving further attention. With the improvement of extraction methods and a better availability of taxonomic keys in the past 10 years (Schmelz and Collado, 2010), our knowledge on enchytraeid taxonomy and ecology as well as their reaction to pesticides have certainly increased considerably, not only in Europe but also for example in Brazil (Chelinho et al., 2012; Assis, 2015). On the other side-and despite the fact that standardized methods are available and new ones are in the making (e.g., Bicho et al., 2015) - the use of enchytraeids in regulatory assessment schemes is still very limited. Indeed, enchytraeids played only a minor role in the risk assessment of pesticides in Europe during the past 25 years, mainly because there were no legal requirements for such tests. However, this situation is going to change, since in the "Draft Scientific Opinion addressing the state of the science on risk assessment of plant protection products for insoil organisms" (EFSA Panel on Plant Protection Products and their Residues (PPR) et al., 2017), Enchytraeidae are one out of seven organisms groups for which Specific Protection Goals (SPGs) are going to be defined, meaning that the relevance of these organisms (and the need to study them) is surely more acknowledged than it has been in the past.

Only few studies addressed the effects of pesticides on enchytraeid communities either under semi-field or field conditions so far. A draft standard method exists for a semifield method, i.e., TMEs (Schaeffer et al., 2010), but nothing like that is available for field tests. However, the standard earthworm field study (International Organization for Standardization, 1999) could be improved by adding potworm abundance and diversity as additional endpoints. In any case, a central part of practical work (extraction of enchytraeids from soil samples) is already covered in an ISO guideline (International Organization for Standardization, 2007), focusing on monitoring enchytraeids. More difficult is the situation for gnotobiotic semifield approaches, since several proposals have been made and the amount of information about their pros and cons is still limited. The most promising method is the SMS (a simplified food-web 


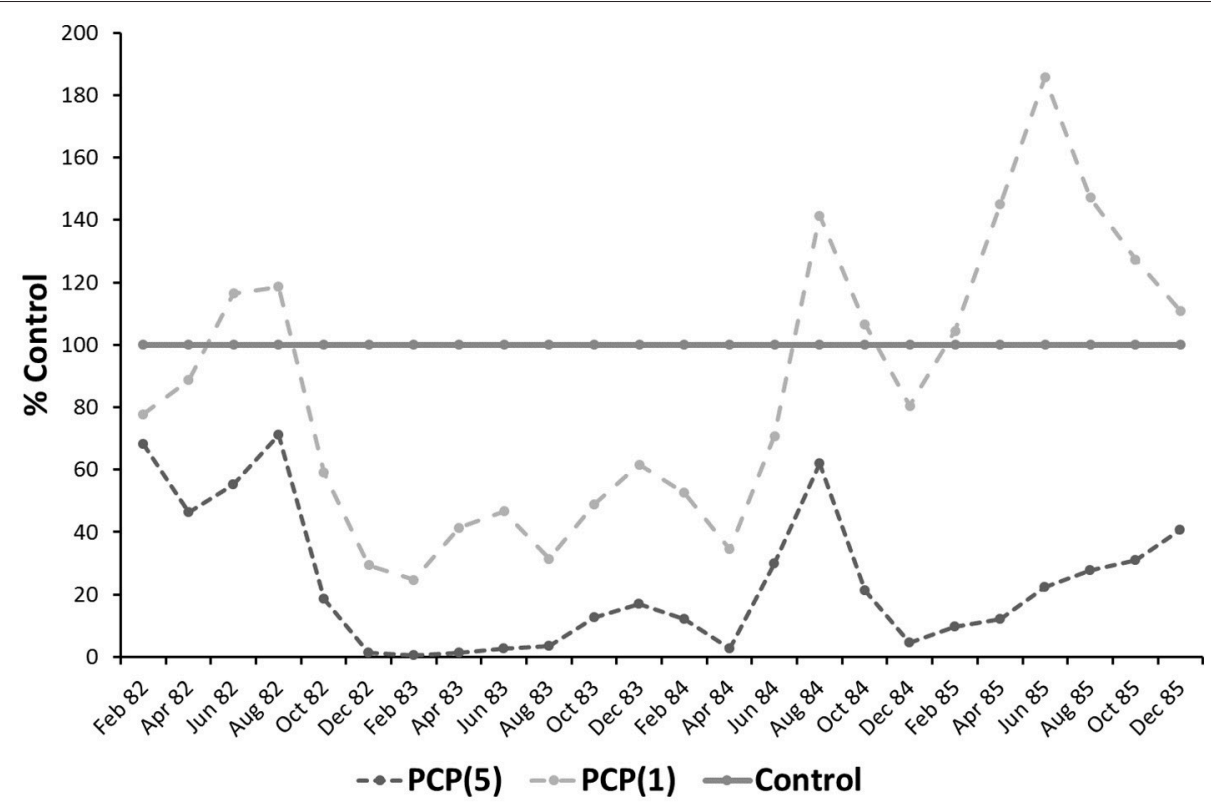

FIGURE 5 | Effects of two concentrations of the fungicide PCP (light gray dotted line: $0.5 \mathrm{~kg} / \mathrm{m}^{2}$; dark gray dotted line: $5 \mathrm{~kg} / \mathrm{m}^{2}$ ) on the enchytraeids of a beech wood forest (bimonthly application: 1982-1983; recovery time: 1984-1985) in percent of the control (solid darkline) (for details see Römbke, 2001).

approach, consisting of springtails, enchytraeids and predatory mites; e.g., Menezes-Oliveira et al., 2014). In fact first studies aiming at its standardization have been published (e.g., Sechi et al., 2014).

The experiences with enchytraeid higher-tier testing can be summarized as follows:

- In these tests total abundance was often the main (or only) endpoint. Higher sensitivity can be expected at the genus or species level, but there are difficulties due to the impracticability of enchytraeid taxonomy. However, this situation is going to improve due to better keys (at least for Europe) as well as the upcoming genetic methods.

- Regarding other endpoints, experience is limited. Total biomass and abundance seem to be correlated. In the few studies in which enchytraeid species were identified a quite high number was found even at crop sites, meaning that diversity is worthwhile to be included.

- The available information is not yet sufficient to clarify whether individual species or genera are more sensitive to a specific pesticide than others. However, species of the genus Fridericia (i.e., K strategists) are more affected by carbendazim than other enchytraeids, which may be due to different exposure or to physiological differences.

- The number of pesticides studied in higher-tier tests with enchytraeids is very low; besides some old compounds and only few currently used PPPs have been investigated. The one exception is carbendazim, which has already been used in a European ring test, both in TMEs and the field. Sensitivity of earthworms and enchytraeids differed by about the factor of three in this ring-test, meaning that each organism groups would have indicated a risk.

- Despite its small number, the results of semi-field and field studies can provide relevant information for the environmental risk assessment of pesticides, as shown for carbendazim. Effects of herbicides may be less relevant in terms of direct toxicity but could be considered as an example of indirect effects (e.g., via change in soil moisture due to plant removal).

- By definition, higher-tier studies do include site-specific properties (which means mainly soil properties but also climatic factors) and this inclusion of realism has to be addressed in current risk assessment procedures. In fact, in modern TME facilities realistic climatic scenarios can be simulated. In this context the "Normal Operating Ranges" (NORs) of at least the most common enchytraeid species should be determined, preferably using soil biodiversity data bases (e.g., Burkhardt et al., 2014).

- The information available from higher-tier studies does allow to draw important conclusions, for example when addressing the question how much the composition of invertebrate communities determines the level of ecotoxicity (Sechi et al., 2014). Another example is the interaction between (changing) climate parameters with chemicals, which in turn can cause unpredictable changes in community structures (MenezesOliveira et al., 2014).

- Last but not least such semi-field and field studies are necessary to "validate" the results of lower tier studies and/or for the development of realistic modeling approaches. 


\section{KNOWLEDGE GAPS AND PERSPECTIVES}

As shown above there are still various issues regarding the effects of pesticides on enchytraeids which need further research. Among them are basic questions referring to their biology and ecology, such as:

- How much differs sensitivity among individual species? Are the species used in standard tests (mainly E. albidus, E. crypticus) representative in terms of sensitivity for the whole family?

- It is possible to use metabolic pathways of enchytraeids in order to address metabolic effects of pesticides and to reveal the cascade of responses at the lower levels of biological organization?

- How do enchytraeids incorporate pesticides, i.e., which are the main exposure pathways and how much do they depend on soil properties or on chemical characteristics (Gomes et al., 2011; Peijnenburg et al., 2012)?

- Which endpoints are the most sensitive, relevant, robust and practical ones? Reproduction surely comes first but is timeconsuming. Could genetic markers take over this role while being quicker to perform (Amorim et al., 2011)?

- What about the trait concept-can we identify morphological/ecological groups which may be more relevant than individual species?

- Is it possible to overcome taxonomic burdens by building up a database containing enchytraeid gene sequences so that enchytraeid diversity could be an "easy" endpoint in field studies or monitoring approaches?

In a regulatory context, further questions have to be answered (most of them are important for other soil organisms too; Van Gestel, 2012):

- How could bioavailability be included in ERA schemes without losing protectivity?

- Should the information gained in sub-individual studies be involved in regulatory risk assessment and if yes, how?

- How can enchytraeids be established in higher-tier tests such as TMEs or field tests-and would it be useful to standardize gnotobiotic test systems?

- How can relevant protection goals for enchytraeids be defined, both for their functional roles and for their diversity (EFSA Panel on Plant Protection Products and their Residues (PPR) et al., 2017)?

- How much do interactions with other soil organisms account when discussing the effects of pesticides on enchytraeids (Menezes-Oliveira et al., 2011)?

Pesticides are just one factor potentially affecting enchytraeids in the field. Almost no information is available on the interactive effects on enchytraeids of pesticides applied together (as mixtures) or as part of normal agricultural practice. Similarly, no information could be found on the effects of adjuvants. In temperate regions, crop plants are often treated with several formulations of pesticides per season, while under tropical conditions more than 10 applications may occur within the same period (Waichman et al., 2002). Such realistic scenarios have never been investigated regarding their influence on enchytraeids. Almost the same is true regarding the interaction between pesticides and other agricultural practices (e.g., soil compaction due to the use of heavy machinery; Beylich et al., 2010). Finally, interactions between pesticide use and changing environmental conditions (in particular, temperature and soil moisture) in the context of Global Climate Change, could be important. Actually, based on studies with E. albidus and nonylphenol (included in some fungicide formulations), Silva et al. (2016) recommended to include environmental factors such as salinization in standard test procedures. Surely, such modifications should be investigated more intensively.

Enchytraeids are potentially affected by pesticides world-wide, but so far these organisms have been neglected in most parts of the world, with the notable exception of Brazil (Niva et al., 2016). Therefore, considering their key roles in soils, laboratory, semi-field, and field studies are urgently needed in most parts of the world-of course only in those in which enchytraeids are abundant enough to be used as indicators (e.g., not in permanently dry regions).

As mentioned above, the regulations for the risk assessment of pesticides in Europe are currently under discussion (EFSA Panel on Plant Protection Products and their Residues (PPR) et al., 2017). Enchytraeids are one out of seven soil organism groups for which specific protection goals have been definedand they are quite detailed regarding the magnitude and duration of effects. However, it is not clear whether the expectations of this document can be fulfilled by the existing test methods. While this is probably no problem for laboratory tests (especially when including recent ideas on life-cycling testing; Bicho et al., 2015), there is surely work to be done on higher-tier testing. Regarding semi-field tests (e.g., TMEs), the main problem is the formal standardization of existing approaches (Schaeffer et al., 2010). In contrast, there is no detailed proposal for an enchytraeid field test, despite the fact that the well-known earthworm field test (International Organization for Standardization, 1999) could probably be combined with enchytraeid samplings as described in monitoring guidelines (International Organization for Standardization, 2007).

\section{CONCLUSIONS}

The information provided in this paper can be summarized as follows:

- The existing information on the effects of pesticides on enchytraeids in agro-ecosystems has been compiled.

- Few pesticides have been tested in comparison to the total number of PPPs commonly used in agroecosystems.

- Enchytraeidae are common soil invertebrates, which at least in some soils can occur in high numbers and diversity. However, due to their small size and for taxonomic reasons, they are less considered in ecology and ecotoxicology than, for example, their larger relatives, earthworms.

- For these reasons, they are not regularly tested in the context of pesticide environmental risk assessment. However, standard laboratory tests were developed and their inclusion in existing semi-field and field test methods was proposed and seems to 
be possible with limited efforts. They they are one out of seven soil organism groups for which specific protection goals (SPGs) have recently been formulated.

- There are good reasons why they should be used more regularly: laboratory tests do require not much space or amounts of soil. A wide range of standard test methods is available, and more are in the making (e.g., multi-generation tests).

- Even more obvious are advantages in higher-tier tests: in TME tests complex interactions with other soil organisms under a wide range of environmental conditions can be studied with relatively low efforts in comparison to field tests.

- Independently from the test level, enchytraeids are very useful for the study of interactions between pesticides and biotic or abiotic stress factors (mainly soil properties but also anthropogenic factors such as Global Climate Change).

- Although enchytraeid ecology and ecotoxicology is clearly biased toward studies in European temperate conditions, good examples of their use as test organisms and bioindicators are also present in Mediterranean and tropical environments; this should motivate researchers worldwide to dedicate attention

\section{REFERENCES}

Abrahamsen, G., and Thompson, W. N. (1979). A long term study of the enchytraeid (Oligochaeta) fauna of a mixed coniferous forest and the effects of urea fertilization. Oikos 32, 318-327. doi: 10.2307/3544742

Achazi, R. K., Fröhlich, E., Henneken, M., and Pilz, C. (1999). The effect of soil from former irrigation fields and of sewage sludge on dispersal activity and colonizing success of the annelid Enchytraeus crypticus (Enchytraeidae, Oligochaeta). Newsl. Enchytr. 6, 117-126.

American Society for Testing and Materials (1993). "Standard guide for conducting a terrestrial soil-core microcosm test," in Annual Book, Vol. 1197 (West Conshohocken, PA: ASTM), 546-557.

American Society for Testing and Materials (2004). Standard Guide for Conducting Laboratory Soil Toxicity or Bioaccumulation Tests with the Lumbricid Earthworm Eisenia fetida and the Enchytraeid Potworm Enchytraeus albidus. West Conshohocken, PA: ASTM. ASTM Guideline No. E 1676-97.

Amorim, M. J. B., Novais, S. C., van der Ven, K., Vandenbrouck, T., Soares, A. M. V. M., and de Coen, W. (2011). Development of a microarray for Enchytraeus albidus (Oligochaeta): preliminary tool with diverse applications. Environ. Toxicol. Chem. 30, 1395-1402. doi: 10.1002/etc.512

Amorim, M. J. B., Novais, S., Römbke, J., and Soares, A. M. V. M. (2008a). Avoidance test with Enchytraeus albidus (Enchytraeidae): effects of different exposure time and soil properties. Environmental Pollution 155, 112-116. doi: 10.1016/j.envpol.2007.10.028

Amorim, M. J. B., Novais, S., Römbke, J., and Soares, A. M. V. M. (2008b). Enchytraeus albidus (Enchytraeidae): a test organism in a standardised avoidance test? Effects of different chemical substances. Environ. Int. 34, 363-371. doi: 10.1016/j.envint.2007.08.010

Amorim, M. J. B., Römbke, J., Scheffczyk, A., and Soares, A. M. V. M. (2005a). Effect of different soil types on the enchytraeids Enchytraeus albidus and Enchytraeus luxuriosus using the herbicide phenmedipham. Chemosphere 61, 1102-1114. doi: 10.1016/j.chemosphere.2005.03.048

Amorim, M. J. B., Römbke, J., and Soares, A. M. V. M. (2005b). Avoidance behaviour of Enchytraeus albidus: effects of benomyl, carbendazim, phenmedipham and different soil types. Chemosphere 59, 501-510. doi: 10.1016/j.chemosphere.2005.01.057

Amorim, M. J. B., Sousa, J. P., Nogueira, A. J. A., and Soares, A. M. V. M. (1999). Comparison of chronic toxicity of Lindane (gamma-HCH) to Enchytraeus albidus in two soil types: the influence of soil pH. Pedobiologia 43, 635-640. to these important but overlooked key players of soil food webs.

\section{AUTHOR CONTRIBUTIONS}

The authors did equally contribute to the design, data acquisition, data interpretation, drafting, and critical reviewing of this work. JR, RS, and CP approved this final version and agree to be accountable for all aspects presented here.

\section{ACKNOWLEDGMENTS}

We thank Nicola Böffinger for her help identifying and collecting the literature used in this review and Stephan Jänsch for his critical comments on earlier versions of this manuscript.

\section{SUPPLEMENTARY MATERIAL}

The Supplementary Material for this article can be found online at: http://journal.frontiersin.org/article/10.3389/fenvs. 2017.00020/full\#supplementary-material

Amorim, M. J., Sousa, J. P., Nogueira, A. J. A., and Soares, A. M. V. M. (2002). Bioavailability and Toxicokinetics of $14 \mathrm{C}$-Lindane $(\gamma-\mathrm{HCH})$ in the Enchytraeid Enchytraeus albidus in two soil types: the aging effect. Arch. Environ. Contamin. Toxicol. 43, 221-228. doi: 10.1007/s00244-002-1162-y

Amorim, M., Soares, A. M. V. M., and Römbke, J. (2005). Comparison of the influence of an artificial and a natural soil on the behaviour of Enchytraeus albidus - laboratory tests. Proc. Eston. Acad. Sci. Biol. Ecol. 54, 335-341.

An, Y.-J., and Yang, C.-Y. (2009). Fridericia peregrinabunda (Enchytraeidae) as a new test species for soil toxicity assessment. Chemosphere 77, 325-329. doi: 10.1016/j.chemosphere.2009.07.013

Arrate, J., Angel, R. P., and Martinez-Madrid, M. (2002). Effects of three chemicals on the survival and reproduction of the oligochaete worm Enchytraeus coronatus in chronic toxicity tests. Pedobiologia 46, 136-149. doi: 10.1078/0031-4056-00120

Assis, O. (2015). Enchytraeids (Enchytraeidae, Oligochaeta) as Indicators of Soil Management and Ecotoxicological Tests. Dissertation, Universidade Tecnológica Federal do Paraná, Curitiba.

Associação Brasileira de Normas Técnicas (2012). Qualidade do Solo - Efeitos de Poluentes em Enchytraeidae (Enchytraeus sp.) - Determinação de Efeitos sobre a Reprodução e Sobrevivência. Rio de Janeiro: ABNT, No. ISO: 16387.

Augustsson, A. K., and Rundgren, S. (1998). The enchytraeid Cognettia sphagnetorum in risk assessment: advantages and disadvantages. Ambio 27, 62-69.

Bandow, C., Coors, A., and Römbke, J. (2013). Enchytraeus bigeminus (Enchytraeidae, Oligochaeta) as a new candidate for ecotoxicological laboratory tests. Soil Organisms 85, 103-112.

Bandow, C., Ng, E. L., Schmelz, R. M., Sousa, J., Paulo, and Römbke, J. (2016). A TME study with the fungicide pyrimethanil combined with different moisture regimes: effects on enchytraeids. Ecotoxicology 25, 213-224. doi: 10.1007/s10646-015-1581-y

Banerjee, B. D., Seth, V., and Ahmed, R. S. (2001). Pesticide-induced oxidative stress: perspective and trends. Rev. Environ. Health 16, 1-40. doi: 10.1515/REVEH.2001.16.1.1

Barth, N., Brandtner, W., Cordsen, E., Dann, T., Emmerich, K.-H., Feldhaus, D., et al. (2000). "Boden-Dauerbeobachtung - Einrichtung und Betrieb von Boden-Dauerbeobachtungsflächen,” in Bodenschutz. Kennziffer 9152, eds D. Rosenkranz, G. Bachmann, W. König, and G. Einsele (Berlin: Erich Schmidt Verlag), 1-127. 
Bengtsson, G., and Rundgren, S. (1982). Population density and species number of enchytraeids in coniferous forest soils polluted by a brass mill. Pedobiologia 24, 211-218.

Beylich, A., and Graefe, U. (2009). Investigations of annelids at soil monitoring sites in Northern Germany: reference ranges and time-series data. Soil Organisms 81, 175-196.

Beylich, A., Oberholzer, H.-R., Schrader, S., Höper, H., and Wilke, B.-M. (2010). Evaluation of soil compaction effects on soil biota and soil biological processes in soils. Soil Tillage Res. 109, 133-143. doi: 10.1016/j.still.2010.05.010

Bezchlebová, J., Černohlávková, J., Lána, J., Sochová, I., Kobetičová, K., and Hofman, J. (2007). Effects of toxaphene on soil organisms. Ecotoxicol. Environ. Saf. 68, 326-334. doi: 10.1016/j.ecoenv.2007.05.009

Bicho, R. C., Santos, F. C. F., Gonçalves, M. F. M., Soares, A. M. V. M., and Amorim, M. J. B. (2015). Enchytraeid Reproduction TestPLUS: hatching, growth and full life cycle test-An optional multiendpoint test with Enchytraeus crypticus. Ecotoxicology 24, 1053-1063. doi: $10.1007 /$ s10646-015-1445-5

Bispo, A., Cluzeau, D., Creamer, R., Dombos, M., Graefe, U., Krogh, P., et al. (2009). Indicators for monitoring soil biodiversity. Integr. Environ. Assess. Manag. 5, 717-719. doi: 10.1897/IEAM-2009-064.1

Born, H. (1993). Die Sukzession der Enchytraeen-Synusie (Annelida, Oligochaeta) eines Ruderalökosystems unter Natürlichen und Anthropogenen Einflüssen. Dissertation, Universität Bremen, Bremen.

Brüggl, G. (1994). Populationsentwicklung von Enchytraeus crypticus (Enchytraeidae, Oligochaeta) und Einfluss subletaler Pestizidbelastungen unter Laborbedingungen. Dissertation, University of Osnabrück, Osnabrück.

Bruns, E., Egeler, P., Roembke, J., Scheffczyk, A., and Spoerlein, P. (2001). Bioaccumulation of lindane and hexachlorobenzene by the oligochaetes Enchytraeus luxuriosus and Enchytraeus albidus (Enchytraeidae, Oligochaeta, Annelida). Hydrobiologia 463, 185-196. doi: 10.1023/A:1013159810067

Brussaard, L. (2012). "Ecosystem services provided by the soil biota," in Soil Ecology and Ecosystem Services, eds D. H. Wall, R. D. Bardgett, V. Behan-Pelletier, J. E. Herrick, H. Jones, K. Ritz, J. Six, D. R. Strong, and W. H. van der Putten (Oxford: Oxford University Press), 45-58.

Burkhardt, U., Russell, D. J., Buryn, R., Decker, P., Döhler, M., Höfer, H., et al. (2014). The Edaphobase Project of GBIF-Germany - a new online soil- organism zoological data warehouse. Appl. Soil Ecol. 83, 5-12. doi: 10.1016/j.apsoil.2014.03.021

Burrows, L. A., and Edwards, C. A. (2004). The use of integrated soil microcosms to assess the impact of carbendazim on soil ecosystems. Ecotoxicology 13, 143-161. doi: 10.1023/B:ECTX.0000012411.14680.21

Castro-Ferreira, M. P., Roelofs, D., van Gestel, C., Verweij, R. A., Soares, A. M. V. M., and Amorim, M. J. B. (2012). Enchytraeus crypticus as model species in soil ecotoxicology. Chemosphere 87, 1222-1227. doi: 10.1016/j.chemosphere.2012.01.021

Chalupský, J. Jr. (1989). The influence of Zeazin 50 on Enchytraeidae (Oligochaeta) in an apple orchard soil. Pedobiologia 33, 361-371.

Chalupský, J. Jr., and Lepš, J. (1985). The spatial pattern of Enchytraeidae (Oligochaeta). Oecologia 68, 153-157. doi: 10.1007/BF00379488

Chelinho, S., Domene, X., Campana, P., Andrés, P., Römbke, J., Sousa, J., et al. (2014). Toxicity of phenmedipham and carbendazim to Enchytraeus crypticus and Eisenia andrei (Oligochaeta) in Mediterranean soils. J. Soils Sediments 14, 584-599. doi: 10.1007/s11368-013-0818-8

Chelinho, S., Lopes, I., Natal-da-Luz, T., Domene, X., Tenorio Nunes, M. E., Espíndola, E. L. G., et al. (2012). Integrated ecological risk assessment of pesticides in tropical ecosystems: a case study with carbofuran in Brazil. Environ. Toxicol. Chem. 31, 437-445. doi: 10.1002/etc.738

Christensen, B., and Jensen, L. O. (1995). "Toxicity of pesticides to Enchytraeus bigeminus" in Effects of pesticides on meso- and microfauna in soil, ed H. Løkke (Copenhague: Ministry of Environment and Energy), 33-38.

Collado, R., Hass-Cordes, E., and Schmelz, R. M. (2012). Microtaxonomy of fragmenting Enchytraeus species using molecular markers, with a comment on species complexes in enchytraeids. Turk. J. Zool. 36, 85-94. doi: 10.3906/zoo-1002-70

Collado, R., Schmelz, R. M., Moser, T., and Römbke, J. (1999). Enchytraeid reproduction test (ERT): sublethal responses of two Enchytraeus species (Oligochaeta) to toxic chemicals. Pedobiologia 43, 625-629.
Commission of the European Communities (1991). Council directive 91/414/EEC of 15 July 1991 concerning the placing of plant protection products on the market. Official J. Eur. Commun. L 230/1.

Cortet, J., Gomot-De Vauflery, A., Poinsot-Balaguer, N., Gomot, L., Texier, C., and Cluzeau, D. (1999). The use of invertebrate soil fauna in monitoring pollutant effects. Eur. J. Soil Biol. 35, 115-134. doi: 10.1016/S1164-5563(00)00116-3

de Amorim, M. J., Sousa, J. P., Nogueira, A. J. A., and Soares, A. M. V. M. (2002). Bioaccumulation and elimination of 14C-lindane by Enchytraeus albidus in artificial (OECD) and a natural soil. Chemosphere 49, 323-329. doi: 10.1016/S0045-6535(02)00322-3

Didden, W. A. M. (1990). Involvement of Enchytraeidae (Oligochaeta) in soil structure evolution in agricultural fields. Biol. Fertil. Soils 9, 152-158. doi: 10.1007/BF00335799

Didden, W. A. M. (1993). Ecology of terrestrial Enchytraeidae. Pedobiologia 37, $2-29$.

Didden, W. A. M., Fründ, H. L., and Graefe, U. (1997). "Enchytraeids", in Fauna in Soil Ecosystems - Recycling Processes, Nutrient Fluxes and Agricultural Production, ed G. Benckiser (Giessen: M. Dekker, Inc.), 135-172.

Didden, W., and Römbke, J. (2001). Enchytraeids as indicator organisms for chemical stress in terrestrial ecosystems. Ecotoxicol. Environ. Saf. 50, 25-43. doi: 10.1006/eesa.2001.2075

Dormidontova, G. N. (1973). The effect of an insecticide on soil forming fauna (Arthropoda, Oligochaeea). Pedobiologia 13, 123-139.

Dózsa-Farkas, K. (1991). New enchytraeid species found very deep in soils of a hornbeam and oak forest in Hungary (Oligochaeta, Enchytraeidae). Acta Zool. Hung. 37, 21-25.

European Chemicals Agency (2014). Guidance on Information Requirements and Chemical Safety Assessment, Vol. 5, Helsinki: European Chemicals Agency.

Edwards, C. A., and Lofty, J. R. (1971). "Nematicides and the soil fauna," in Proceedings of the Sixth British Insecticide and Fungicide, Vol. 1 (Brighton).

Edwards, C. A., Thompson, A. R., and Beynon, K. I. (1968). Some effects of chlorfenvinphos, an organophosphorus insecticide on populations of soil animals. Rev. Ecol. Biol. Sol. 1, 199-224.

EFSA Panel on Plant Protection Products and their Residues (PPR), Ockleford, C., Adriaanse, P., Berny, P., Brock, T., Duquesne, S., et al. (2017). Scientific Opinion addressing the state of the science on risk assessment of plant protection products for in-soil organisms. EFSA J. 15:e4690. doi: $10.2903 /$ j.efsa.2017.4690

European Plant Protection Organisation (2003). "Chapter 8: Soil organisms and functions," in Environmental Risk Assessment Scheme of Plant Protection Products, Vol. 33 (Paris: EPPO Bulletin), 195-209.

European Commission (2009). Regulation (EC) 1107/2009 of the European Parliament and of the Council of 21 October 2009 Concerning the Placing of Plant Protection Products on the Market and repealing Council Directives 79/117/EEC and 91/414/EEC, Vol. 309. Brussels: Official Journal of the European Union.

Ferreira, M. P. C., Roelofs, D., van Gestel, C. A. M., Amorim, M. J. B., and Soares, A. (2010). Ultra-high Throughput TRANScryptOME Sequencing of Enchytraeus crypticus - Innovative Tool for Stress Response Assessment. Comp. Biochem. Physiol. Mol. Integr. Physiol. 157, S32-S32. doi: 10.1016/j.cbpa.2010.06.092

Förster, B., Garcia, M., Francimari, O., and Römbke, J. (2006). Effects of carbendazim and lambda-cyhalothrin on soil invertebrates and leaf litter decomposition in semi-field and field tests under tropical conditions (Amazonia, Brazil). Eur. J. Soil Biol. 42, 171-179. doi: 10.1016/j.ejsobi.2006.07.011

Förster, B., van Gestel, C., Koolhaas, J. E., Nentwig, G., Rodrigues, J. M. L., and Sousa, J. P. (2004). Ring-testing and field-validation of a terrestrial model ecosystem (TME)-an instrument for testing potentially harmful substances: effects of carbendazim on organic matter breakdown and soil fauna feeding activity. Ecotoxicology 13, 129-141. doi: 10.1023/B:ECTX.0000012410.99020.97

Frampton, G. K., Jänsch, S., Scott-Fordsmand, J. J., Römbke, J., and van den Brink, P. J. (2006). Effects of pesticides on soil invertebrates in laboratory studies: a review and analysis using species sensitivity distributions. Environ. Toxicol. Chem. 25, 2480-2489. doi: 10.1897/05-438R.1

Friberg, H., Fayolle, L., Edel-Hermann, V., Gautheron, N., and Steinberg, C. F. C. (2009). Response of Rhizoctonia solani to soil faunal grazing and organic amendments - different from general microbial dynamics. IOBC/WPRS Bull. $42,63-67$. 
Gomes, S. I. L., Novais, S. C., Soares, A. M. V. M., and Amorim, M. J. B. (2011). Effects of soil properties and time of exposure on gene expression of Enchytraeus albidus (Oligochaeta). Soil Biol. Biochem. 43, 2078-2084. doi: 10.1016/j.soilbio.2011.06.006

Gomes, S. I. L., Soares, A. M. V. M., and Amorim, M. J. B. (2015). Changes in cellular energy allocation in Enchytraeus crypticus exposed to copper and silver-linkage to effects at higher level (reproduction). Environ. Sci. Pollut. Res. 22, 14241-14247. doi: 10.1007/s11356-015-4630-4

Gonçalves, M. F. M., Bicho, R. C., Rêma, A., Soares, A. M. V. M., Faustino, A., and Amorim, M. J. B. (2015). Development of an embryotoxicity test for Enchytraeus crypticus-The effect of Cd. Chemosphere 139, 386-392. doi: 10.1016/j.chemosphere.2015.07.021

Graefe, U. (1993). Die Gliederung von Zersetzergesellschaften für die standortsökologische Ansprache. Mitteilungen der Deutschen Bodenkundlichen Gesellschaft 69, 95-98.

Graefe, U., and Beylich, A. (2003). "Critical values of soil acidification for annelid species and the decomposer community," in Newsletter on Enchytraeidae, Vol. 8, eds W. Didden, and P. Van Vliet (Wageningen: Department of Soil Quality, Wageningen University), 51-55.

Graefe, U., and Schmelz, R. M. (1999). "Indicator values, strategy types and life forms of terrestrial Enchytraeidae and other microannelids," in Newsletter on Enchytraeidae, Vol. 6, eds R. Schmelz, and K. Sühlo (Osnabrück: Universitätsverlag Rasch), 59-67.

Hartnik, T., Sverdrup, L. E., and Jensen, J. (2008). Toxicity of the pesticide alphacypermethrin to four soil nontarget invertebrates and implications for risk assessment. Environ. Toxicol. Chem. 27, 1408-1415. doi: 10.1897/07-385.1

Heungens, A. (1968). The influence of DBCP on the soil fauna in Azalea culture. Pedobiologia 8, 281-288.

Hopkin, S. P. (1989). Ecophysiology of Metals in Terrestrial Invertebrates. New York, NY: Elsevier Applied Science.

Howcroft, C. F., Amorim, M. J. B., Gravato, C., Guilhermino, L., and Soares, A. M. V. M. (2009). Effects of natural and chemical stressors on Enchytraeus albidus: can oxidative stress parameters be used as fast screening tools for the assessment of different stress impacts in soils? Environ. Int. 35, 318-324. doi: 10.1016/j.envint.2008.08.004

Howcroft, C. F., Gravato, C., Amorim, M. J. B., Novais, S. C., Soares, A. M. V. M., and Guilhermino, L. (2011). Biochemical characterization of cholinesterases in Enchytraeus albidus and assessment of in vivo and in vitro effects of different soil properties, copper and phenmedipham. Ecotoxicology 20, 119-130. doi: 10.1007/s10646-010-0562-4

International Organization for Standardization (1998). Soil Quality-Effects of Pollutants on Earthworms (Eisenia fetida). Part 2: Determination of Effects on Reproduction. Geneva: ISO 11268-2.

International Organization for Standardization (1999). Soil Quality - Effects of Pollutants on Earthworms - Part 3: Guidance on the Determination of Effects in Field Situations. Geneva: ISO 11268-3.

International Organization for Standardization (2004). Soil Quality - Effects of Pollutants on Enchytraeidae (Enchytraeus sp.). Determination of Effects on Reproduction and Survival. Geneva: ISO 16387.

International Organization for Standardization (2007). Soil Quality - Sampling of Soil Invertebrates Part 3: Sampling and Soil Extraction of Enchytraeids. Geneva: ISO 23611-3.

International Organization for Standardization (2008). Soil Quality - Avoidance Test for Evaluating the Quality of Soils and the Toxicity of Chemicals. Test with Earthworms (Eisenia fetida/andrei). Geneve: ISO 17512-1.

Jänsch, S., Frampton, G. K., Römbke, J., Van den Brink, P. J., and Scott-Fordsmand, J. J. (2006). Effects of pesticides on soil invertebrates in model ecosystem and field studies: a review and comparison with laboratory toxicity data. Environ. Toxicol. Chem. 25, 2490-2501. doi: 10.1897/05-439R.1

Jänsch, S., Römbke, J., and Didden, W. (2005). The use of enchytraeids in ecological classification and assessment concepts. Ecotoxicol. Environ. Saf. 62, 266-277. doi: 10.1016/j.ecoenv.2004.10.025

Jarratt, N., and Thompson, H. (2009). Comparison between the Sensitivity of Enchytraeids and Lumbricidae to Chemicals, in Particular Plant Protection Products. York, UK: EFSA Supporting Publications.

Jensen, J., and Scott-Fordsmand, J. J. (2012). Ecotoxicity of the veterinary pharmaceutical ivermectin tested in a soil multi-species (SMS) system. Environ. Pollut. 171, 133-139. doi: 10.1016/j.envpol.2012.07.014
Kattwinkel, M., Liess, M., Arena, M., Bopp, S., Streissl, F., and Römbke, J. (2015). Recovery of aquatic and terrestrial populations in the context of European pesticide risk assessment. Environ. Rev. 23, 382-394. doi: 10.1139/er-201 5-0013

Kitazawa, Y., and Kitazawa, T. (1980). "Influence of application of a fungicide, an insecticide, and compost upon soil biotic community," in Soil Biology as Related to Land Use Practices, ed D. L. Dindal (Washington, DC: Office of Pesticide and Toxic Substances, Environmental Protection Agency), 94-99.

Knacker, T., Van Gestel, C. A. M., Jones, S. E., Soares, A. M. V. M., Schallnaß, H.-J., Förster, B., et al. (2004). Ring-testing and field validation of a terrestrial model ecosystem (TME) - an instrument for testing potentially harmful substances: conceptual approach and study design. Ecotoxicology 13, 5-23. doi: 10.1023/B:ECTX.0000012402.38786.01

Kobetičová, K., Hofman, J., and Holoubek, I. (2009). Avoidance response of Enchytraeus albidus in relation to carbendazim ageing. Environ. Pollut. 157, 704-706. doi: 10.1016/j.envpol.2008.09.032

Kremen, C. (2005). Managing ecosystem services: what do we need to know about their ecology? Ecol. Lett. 8, 468-479. doi: 10.1111/j.1461-0248.2005.00751.x

Kristufek, V., and Ruzicka, V. (1995). "Herbicide effects on the reproduction of Enchytraeus crypticus (Oligochaeta)," in 8th International Bioindicators Symposium (Ceske Budejovice).

Kuperman, R. G., Amorim, M. J. B., Römbke, J., Lanno, R., Checkai, R. T., Dodard, S. G., et al. (2006). Adaptation of the enchytraeid toxicity test for use with natural soil types. Eur. J. Soil Biol. 42, 234-243. doi: 10.1016/j.ejsobi.2006.07.028

Kuperman, R. G., Simini, M., Phillips, C. T., and Checkai, R. T. (1999). Comparison of malathion toxicity using enchytraeid reproduction test and earthworm toxicity test in different soil types. Pedobiologia 43, 630-634.

Laakso, J., and Setälä, H. (1999). Sensitivity of primary production to changes in the architecture of belowground food webs. Oikos 87, 57-64. doi: 10.2307/3546996

Lagerlöf, J., Andren, O., and Paustian, K. (1989). Dynamics and contribution to carbon flows of Enchytraeidae (Oligochaeta) under four cropping systems. J. Appl. Ecol. 26, 183-199. doi: 10.2307/2403660

Lavtižar, V., Berggren, K., Trebše, P., Kraak, M. H. S., Verweij, R. A., and van Gestel, C. (2016). Comparative ecotoxicity of chlorantraniliprole to non-target soil invertebrates. Chemosphere 159, 473-479. doi: 10.1016/j.chemosphere.2016.06.036

Leitão, S., José Cerejeira, M., Van den Brink, P. J., and Sousa, J. P. (2014). Effects of azoxystrobin, chlorothalonil, and ethoprophos on the reproduction of three terrestrial invertebrates using a natural Mediterranean soil. Appl. Soil Ecol. 76, 124-131. doi: 10.1016/j.apsoil.2013.12.013

Lock, K., and Janssen, C. R. (2002). Multi-generation toxicity of zinc, cadmium, copper and lead to the potworm Enchytraeus albidus. Environ. Pollut. 117, 89-92. doi: 10.1016/S0269-7491(01)00156-7

Lock, K., Schamphelaere, K. A. C., de, and Janssen, C. R. (2002). The effect of lindane on terrestrial invertebrates. Arch. Environ. Contaminat. Toxicol. 42, 217-221. doi: 10.1007/s00244-001-0009-2

Løkke, H., and van Gestel, C. A. M. (1998). Handbook of Soil Invertebrate Toxicity Tests. Chichester, UK: John Wiley \& Sons.

Loureiro, S., Amorim, M. J. B., Campos, B., Rodrigues, S. M. G., and Soares, A. M. V. M. (2009). Assessing joint toxicity of chemicals in Enchytraeus albidus (Enchytraeidae) and Porcellionides pruinosus (Isopoda) using avoidance behaviour as an endpoint. Environ. Pollut. 157, 625-636. doi: 10.1016/j.envpol.2008.08.010

Maraldo, K., and Holmstrup, M. (2010). Enchytraeids in a changing climate: a mini-review. Pedobiologia 53, 161-167. doi: 10.1016/j.pedobi.2009.10.003

Marinissen, J. C. Y., and Didden, W. A. M. (1997). Influence of the enchytraeid worm Buchholzia appendiculata on aggregate formation and organic matter decomposition. Soil Biol. Biochem. 29, 387-390. doi: 10.1016/S0038-0717(96)00100-9

Martikainen, E. (1996). Toxicity of dimethoate to some soil animal species in different soil types. Ecotoxicol. Environ. Saf. 33, 128-136. doi: 10.1006/eesa.1996.0016

Martikainen, E., Haimi, J., and Ahtiainen, J. (1998). Effects of dimethoate and benomyl on soil organisms and soil processes-a microcosm study. Appl. Soil Ecol. 9, 381-387. doi: 10.1016/S0929-1393(98)00093-6

Martin, N. A. (1975). Effect of four insecticides on the pasture ecosystem: IV. Enchytraeidae and Diptera larvae heat-extracted in water-filled funnels. N.Z. J. Agric. Res. 18, 313-315. doi: 10.1080/00288233.1975.10423650 
Martinsson, S., Rota, E., and Erséus, C. (2015). Revision of Cognettia (Clitellata, Enchytraeidae): re-establishment of Chamaedrilus and description of cryptic species in the sphagnetorum complex. Syst. Biodivers. 13, 257-277. doi: 10.1080/14772000.2014.986555

McColl, H. P. (1984). Nematicides and field population of enchytraeids and earthworms. Soil Biol. Biochem. 16, 139-143.

Millennium Ecosystem Assessment (2005). Ecosystems and Human Well-being: Synthesis. Washington, DC: Island Press.

Menezes-Oliveira, V. B., Scott-Fordsmand, J. J., Rocco, A., Soares, A. M. V. M., and Amorim, M. J. B. (2011). Interaction between density and $\mathrm{Cu}$ toxicity for Enchytraeus crypticus and Eisenia fetida reflecting field scenarios. Sci. Total Environ. 409, 3370-3374. doi: 10.1016/j.scitotenv.2011.04.033

Menezes-Oliveira, V. B., Scott-Fordsmand, J., Soares, A. M. V. M., and Amorim, M. J. B. (2014). Development of ecosystems to climate change and the interaction with pollution-Unpredictable changes in community structures. Appl. Soil Ecol. 75, 24-32. doi: 10.1016/j.apsoil.2013.10.004

Mercurio, S. D. (2017). Understanding Toxicology - A Biological Approach. Burlington, MA: Jones \& Bartlett Publishers.

Morgan, E., and Knacker, T. (1994). The role of laboratory terrestrial model ecosystems in the testing of potentially harmful substances. Ecotoxicology 3, 213-223. doi: 10.1007/BF00117989

Moser, T., and Römbke, J. (2007). "Enchytraeid species assemblage and dominance spectrum in soils from four different European sites investigated in Terrestrial Model Ecosystems (TME) and in the field," in Newsletter on Enchytraeidae No. 10: Proceedings of the 7th International Symposium on Enchytraeidae (Brno: Folia Facultatis Scientiarum Naturalium Universitatis Masarykianae Brunensis, Biologia), 141-155.

Moser, T., Römbke, J., Schallnass, H.-J., and van Gestel, C. (2007). The use of the multivariate Principal Response Curve (PRC) for community level analysis: a case study on the effects of carbendazim on enchytraeids in Terrestrial Model Ecosystems (TME). Ecotoxicology 16, 573-583. doi: 10.1007/s10646-0070169-6

Moser, T., van Gestel, C., Jones, S. E., Koolhaas, J. E., Rodrigues, J. M. L., and Römbke, J. (2004). Ring-testing and field-validation of a Terrestrial Model Ecosystem (TME) - An instrument for testing potentially harmful substances: effects of carbendazim on enchytraeids. Ecotoxicology 13, 89-103. doi: 10.1023/B:ECTX.0000012407.42358.3e

Mothes-Wagner, U., Reitze, H. K., and Seitz, K.-A. (1992). Terrestrial multispecies toxicity testing: 1 . Description of the multispecies assemblage. Chemosphere 24, 1653-1667. doi: 10.1016/0045-6535(92)90408-J

Mulder, C., Boit, A., Bonkowski, M., de Ruiter, P. C., Mancinelli, G., van der Heijden, M. G. A., et al. (2011). A belowground perspective on Dutch agroecosystems: how soil organisms interact to support ecosystem services. Adv. Ecol. Res. 44, 277-357. doi: 10.1016/B978-0-12-374794-5.00005-5

Natal-da-Luz, T., Moreira-Santos, M., Ruepert, C., Castillo, L. E., Ribeiro, R., and Sousa, J. P. (2012). Ecotoxicological characterization of a tropical soil after diazinon spraying. Ecotoxicology 21, 2163-2176. doi: 10.1007/s10646-012-0970-8

Nielsen, C. O. (1954). Studies on Enchytraeidae: 3. The Micro-Distribution of Enchytraeidae. Oikos 5, 167-178. doi: 10.2307/3565158

Nielsen, C. O. (1955). Studies on Enchytraeidae 5. Factors causing seasonal fluctuations in numbers. Oikos 6, 153-169. doi: 10.2307/3564852

Nielsen, C. O., and Christensen, B. (1959). The Enchytraeidae. Critical revision and taxonomy of European species (Studies on Enchytraeidae VII). Nat. Jutlandica $8-9,1-160$.

Nielsen, C. O., and Christensen, B. (1961). "The Enchytraeidae," in Critical Revision and Taxonomy of European Species. Supplement 1, Vol. 10 (Aarhus: Natura Jutlandica), 1-23.

Nielsen, C. O., and Christensen, B. (1963). "The Enchytraeidae," in Critical Revision and Taxonomy of European Species. Supplement 2, Vol. 10 (Aarhus: Natura Jutlandica), 1-19.

Niva, C. C., Niemeyer, J. C., Rodrigues da Silva Júnior, F. M., Tenório Nunes, M. E., de Sousa, D. L., Silva Aragão, C. W., et al. (2016). Soil Ecotoxicology in Brazil is taking its course. Environ. Sci. Poll. Res. 23, 363-378. doi: 10.1007/s11356-016-6597-1

Novais, S. C., and Amorim, M. J. B. (2013). Changes in cellular energy allocation in Enchytraeus albidus when exposed to dimethoate, atrazine, and carbendazim. Environ. Toxicol. Chem. 32, 2800-2807. doi: 10.1002/etc.2368
Novais, S. C., and Amorim, M. J. B. (2014). Normal operating range (NOR) in Enchytraeus albidus - Transcriptional responses to control conditions. Appl. Soil Ecol. 85, 1-10. doi: 10.1016/j.apsoil.2014.08.005

Novais, S. C., Arrais, J., Lopes, P., Vandenbrouck, T., de Coen, W. and Roelofs, D. (2012a). Enchytraeus albidus microarray: enrichment, design, annotation and database (EnchyBASE). PLoS ONE 7:e34266. doi: 10.1371/journal.pone.0034266

Novais, S. C., de Coen, W., and Amorim, M. J. B. (2012b). Gene expression responses linked to reproduction effect concentrations (EC 10, 20, 50, 90) of dimethoate, atrazine and carbendazim, in Enchytraeus albidus. PLoS ONE 7: e36068. doi: 10.1371/journal.pone.0036068

Novais, S. C., Gomes, N. C., Soares, A. M. V. M., and Amorim, M. J. B. (2014). Antioxidant and neurotoxicity markers in the model organism Enchytraeus albidus (Oligochaeta): mechanisms of response to atrazine, dimethoate and carbendazim. Ecotoxicology 23, 1220-1233. doi: 10.1007/s10646-014-1265-Z

Novais, S. C., Howcroft, C. F., Carreto, L., Pereira, P. M., Santos, M. A. S., de Coen, W., et al. (2012c). Differential gene expression analysis in Enchytraeus albidus exposed to natural and chemical stressors at different exposure periods. Ecotoxicology 21, 213-224. doi: 10.1007/s10646-011-0780-4

Novais, S. C., Soares, A. M. V. M., and Amorim, M. J. B. (2010). Can avoidance in Enchytraeus albidus be used as a screening parameter for pesticides testing? Chemosphere 79, 233-237. doi: 10.1016/j.chemosphere.2010.01.011

Organization for Economic Co-operation and Development (1984). Guideline for Testing of Chemicals No. 207. Earthworm Acute Toxicity test. Paris: Organization for Economic Co-operation and Development.

Organisation for Economic Co-operation and Development (2004). Guideline for the Testing of Chemicals, No. 220. Enchytraeid Reproduction Test. Paris: Organisation for Economic Co-operation and Development.

Organisation for Economic Co-operation and Development (2010). Bioaccumulation in Terrestrial Oligochaetes. Guideline for the testing of chemicals 317. Paris: Organisation for Economic Co-operation and Development.

Orgiazzi, A., Dunbar, M. B., Panagos, P., de Groot, G. A., and Lemanceau, P. (2015). Soil biodiversity and DNA barcodes: opportunities and challenges. Soil Biol. Biochem. 80, 244-250. doi: 10.1016/j.soilbio.2014.10.014

Peachey, J. E. (1963). Studies on the Enchytraeidae (Oligochaeta) of moorland soil. Pedobiologia 2, 81-95.

Peijnenburg, W., Capri, E., Kula, C., Liess, M., Luttik, R., Montforts, M., et al. (2012). Evaluation of exposure metrics for effect assessment of soil invertebrates. Crit. Rev. Environ. Sci. Technol. 42, 1862-1893. doi: 10.1080/10643389.2011.574100

Pelosi, C., and Römbke, J. (2016). Are Enchytraeidae (Oligochaeta, Annelida) good indicators of agricultural management practices? Soil Biol. Biochem. 100, 255-263. doi: 10.1016/j.soilbio.2016.06.030

Petersen, H., and Luxton, M. (1982). A comparative analysis of soil fauna populations and their role in decomposition processes. Oikos 39, 288-388. doi: $10.2307 / 3544689$

Pokarzhevskii, A. D., Filimonova, Z. h. V., and Goryachev, O. A. (2003). Lifecycle length determines the differences in sensitivity to toxicants between Enchytraeid species. Dokl. Biol. Sci. 390, 256-258.

Popovici, I., Stan, G., Stefan, V., Tomescu, R., Dumea, A., Tarta, A., et al. (1977). The influence of Atrazine on soil fauna. Pedobiologia 17, 209-215.

Pryor, W. (1991). The antioxidant nutrients and disease prevention - what do we know and what do we need to find out? Am. J. Clin. Nutr. 53 (Suppl. 1), 391S-393S.

Purschke, G., Hagens, M., and Westheide, W. (1991). Ultrahistopathology of enchytraeid oligochaetes (Annelida) after exposure to pesticides-A means of identification of sublethal effects? Comp. Biochem. Physiol. C Comp. Pharmacol. 100C, 119-122. doi: 10.1016/0742-8413(91)90136-H

Puurtinen, H. M., and Martikainen, E. A. T. (1997). Effect of soil moisture on pesticide toxicity to an enchytraeid worm, Enchytraeus sp. Arch. Environ. Contam. Toxicol. 33, 34-41. doi: 10.1007/s002449900220

Römbke, J. (1988). Die Enchytraeen eines Moderbuchenwaldes, ihre Rolle beim Streuabbau und ihre Reaktion auf Umweltbelastungen. Dissertation, Frankfurt am Main.

Römbke, J. (1989). “Enchytraeus albidus (Oligochaeta, Annelida) as a test organism in terrestrial laboratory systems," in Biological Monitoring of Exposure and the Response at the Subcellular Level to Toxic Substances, Archives of Toxicology, eds 
P. L. Chambers, C. M. Chambers, and H. Greim (Berlin; Heidelberg: Springer), 402-405.

Römbke, J. (1991). Umweltverhalten von Chemikalien in einem terrestrischen Ökosystemausschnitt: Effekte auf Enchytraeidae (Oligochaeta). Verhandlungen Gesellschaft Ökologie 19, 157.

Römbke, J. (2001). Auswirkungen zweier Umweltchemikalien auf die Enchytraeen eines Moderbuchenwalds. Andrias 15, 205-218.

Römbke, J. (2003). Ecotoxicological laboratory tests with enchytraeids: a review. Pedobiologia 47, 607-616. doi: 10.1078/0031-4056-00235

Römbke, J., Beck, L., Dreher, P., Hund-Rinke, K., Jänsch, S., Kratz, W., et al. (2002). Entwicklung von Bodenbiologischen Bodengüteklassen für Acker- und Grünlandstandorte. UBA-Texte 20/02. Federal Environment Agency.

Römbke, J., Dreher, P., Beck, L., Hammel, W., Hund, K., Knoche, H., et al. (2000). Bodenbiologische Bodengüte-Klassen. UBA-Texte 6/00. Federal Environment Agency.

Römbke, J., and Federschmidt, A. (1995). "Effects of the fungicide carbendazim on Enchytraeidae in laboratory and field tests," in Newsletter on Enchytraeidae, Vol. 4, ed R. Bauer (Vienna: University of Agriculture) 79-96.

Römbke, J., Jänsch, S., Höfer, H., Horak, F., Roß-Nickoll, M., Russell, D., et al. (2013). State of knowledge of enchytraeid communities in German soils as a basis for biological soil quality assessment. Soil Organisms 85, 123-146.

Römbke, J., and Knacker, T. (1989). Aquatic toxicity test for enchytraeids. Hydrobiologia 180, 235-242. doi: 10.1007/BF00027556

Römbke, J., Knacker, T., Förster, B., and Marcinkowski, A. (1994). "Comparison of effects of two pesticides on soil organisms in laboratory tests, microcosms and in the field," in Ecotoxicology of Soil Organisms, eds M. Donker, H. Eijsackers, and F. Heimbach (Chelsea, MI: Lewis Publisher), 229-240.

Römbke, J., and Moser, T. (1999). Organisation and Performance of an International Ringtest for the Validation of the Enchytraeid Reproduction Test Vol. I and II. UBA-Texte 4/99. Federal Environment Agency.

Römbke, J., and Moser, T. (2002). Validating the enchytraeid reproduction test: organisation and results of an international ringtest. Chemosphere 46, 1117-1140. doi: 10.1016/S0045-6535(01)00113-8

Römbke, J., Schmelz, R., and Knaebe, S. (2009). Field studies for the assessment of pesticides with soil mesofauna, in particular enchytraeids, mites and nematodes: design and first results. Soil Organisms 81, 234-264.

Rota, E., and Healy, B. (1999). A taxonomic study of some Swedish Enchytraeidae (Oligochaeta), with descriptions of four new species and notes on the genus Fridericia. J. Natl. History 33, 29-64. doi: 10.1080/00222939 9300461

Ruf, A., Beck, L., Römbke, J., and Spelda, J. (2000). Standortspezifische Erwartungswerte für die Gemeinschaftsstruktur ausgewählter Taxa der Bodenfauna als Bodenqualitätskriterium. Berichte NaturwissenschaftlichMedizinischen Vereins in Innsbruck 87, 365-379.

Rutgers, M., Mulder, C., and Schouten, A. J. (eds.). (2008). Soil Ecosystem Profiling in the Netherlands with Ten References for Biological Soil Quality. RIVM-Report 607604009.

Rüther, U., and Greven, H. (1990). The effect of heavy metals on enchytraeids. 1. Uptake from an artificial substrate and influence on food preference. Acta Biol. Benrodis 2, 125-131.

Schaeffer, A., van den Brink, P. J., Heimbach, F., Hoy, S. P., de Jong, F. M. W., Römbke, J., et al. (2010). Guidance from the SETAC Europe Workshop: Semi-field Methods for the Environmental Risk Assessment of Pesticides in Soil (PERAS). Boca Raton, FL: CRC Press.

Schärffenberg, B. (1950). Untersuchungen über die Bedeutung der Enchytraeiden als Humusbildner und Nematodenfeinde. - Z. Pflanzenkrankh. Pflanzenschutz $57,183-191$

Schlaghamerský, J. (2015). Short note on enchytraeid occurrence in deep layers of urban soils. Soil Organisms 87, 85-89.

Schmelz, R. M. (2003). Taxonomy of Fridericia (Oligochaeta, Enchytraeidae). Revision of species with morphological and biochemical methods. Abhandlungen des Naturwissenschaftlichen Vereins in Hamburg (Neue Folge) 38:415.

Schmelz, R. M., and Collado, R. (2010). A guide to European terrestrial and freshwater species of Enchytraeidae (Oligochaeta). Soil Organisms 82, 1-176.

Schmelz, R. M., and Collado, R. (2012). An updated checklist of currently accepted species of Enchytraeidae (Oligochaeta). vTI Agric. Forest. Res. 357, $67-87$.
Schmidt, O., Curry, J. P., Dyckmans, J., Rota, E., and Scrimgeour, C. M. (2004). Dual stable isotope analysis $\left(\delta^{13} \mathrm{C}\right.$ and $\left.\delta^{15} \mathrm{~N}\right)$ of soil invertebrates and their food sources. Pedobiologia 48, 171-180. doi: 10.1016/j.pedobi.2003.12.003

Schoch-Bösken, J., and Römbke, J. (1993). Bibliography of the Enchytraeidae (1950-1991). Acta Biol. Benrodis (Suppl. 1), 1-76.

Scholz-Starke, B., Beylich, A., Moser, T., Nikolakis, A., Rumpler, N., Schäffer, A., et al. (2013). The response of soil organism communities to the application of the insecticide lindane in terrestrial model ecosystems. Ecotoxicology 22, 339-362. doi: 10.1007/s10646-012-1030-0

Schouten, A. J., Breure, A. M., Bloem, J., Didden, W., De Ruiter, P. C., and Siepel, H. (1999). Life Support Functions of the Soil: Operationalization for the Policy. RIVM Report 607601003, National Institute of Public health and the Environment, Bilthoven.

Schrader, S., Thiele, J.-A., and Pacholski, A. (2005). Bodenökologische Bewertung eines Agrarökosystems anhand der räumlichen Variabilität ausgewählter Parameter. Mitteilungen der Deutschen Bodenkundlichen Gesellschaft 107, 205-206.

Scoriza, R. N., Silva, A. D., Correia, M. E. F., Leles, P. S. D., and de Resende, A. S. (2015). Herbicide use in degraded forest areas in restoration: effects on soil invertebrate biota. Rev. Brasil. Ciencia Solo 39, 1576-1584. doi: 10.1590/01000683rbcs20150096

Scott-Fordsmand, J. J., Maraldo, K., and Van den Brink, P. (2008). The toxicity of copper contaminated soil using a gnotobiotic Soil Multi-species test System (SMS). Environ. Int. 34, 524-530. doi: 10.1016/j.envint.2007.11.008

Sechi, V., D’Annibale, A., Maraldo, K., Johansen, A., and Bossi, R. J. (2014). Species composition of a soil invertebrate multi-species test system determines the level of ecotoxicity. Environ. Pollut. 184, 586-596. doi: 10.1016/j.envpol.2013.10.008

Silva, A. L. P., Amorim, M. J. B., and Holmstrup, M. (2015). Salinity changes impact of hazardous chemicals in Enchytraeus albidus. Environ. Toxicol. Chem. 34, 2159-2166. doi: 10.1002/etc.3058

Silva, A. L. P., Amorim, M. J. B., and Holmstrup, M. (2016). Adaptations of enchytraeids to single and combined effects of physical and chemical stressors. Environ. Rev. 24, 1-12. doi: 10.1139/er-2015-0048

Spurgeon, D. J., Morgan, A. J., and Kille, P. (2008). "Current research in soil invertebrate ecotoxicogenomics," in Comparative Toxicogenomics, eds C. Hogstrand and P. Kille (Oxford: Elsevier), 133-163.

Standen, V. (1973). The production and respiration of an enchytraeid population in blanked bog. J. Animal Ecol. 42, 219-245. doi: 10.2307/3282

Standen, V. (1984). Production and diversity of enchytraeid earthworms and plants in fertilized hay meadow plots. J. Animal Ecol. 21, 293-312. doi: $10.2307 / 2403055$

Stringer, A., and Wright, M. A. (1973). The effect of benomyl and some Related compounds on Lumbricus terrestris and other earthworms. Pest. Sci. 4, 165-170. doi: 10.1002/ps.2780040202

Topoliantz, S., Ponge, J.-F., and Viaux, P. (2000). Earthworm and enchytraeid activity under different arable farming systems, as exemplified by biogenic structures. Plant Soil 225, 39-51. doi: 10.1023/A:1026537632468

Turbé, A., De Toni, A., Benito, P., Lavelle, P., Ruiz, N., Van der Putten, W. H., et al. (2010). Soil Biodiversity: Functions, Threats, and Tools for Policy Makers. BioIntelligence Service. IRD. and NIOO. Report for European Commission (DG Environment), Brussels.

Van den Brande, J., and Heungens, A. (1969). Influence of repeated applications of nematicides on the soil fauna in Begonia culture. Neth. J. Plant Pathol. 75, 40-44. doi: 10.1007/BF02137191

Van Gestel, C. A. M. (2012). Soil ecotoxicology: state of the art and future directions. ZooKeys 176, 275-296. doi: 10.3897/zookeys.176.2275

Van Vliet, P. C. J., West, L. T., Hendrix, P. F., and Coleman, D. C. (1993). The influence of Enchytraeidae (Oligochaeta) on the soil porosity of small microcosms. Geoderma 56, 287-299. doi: 10.1016/0016-7061(93)90118-5

VICH (2005). Environmental Impact Assessment (EIAs) for Veterinary Medicinal Products (VMPs) - Phase II Guidance. VICH Guideline 38 (Ecotoxicity Phase II). CVMP/VICH/790/03-FINAL. International Cooperation on Harmonisation of Technical Requirements for Registration of Veterinary Medicinal Products, London.

Voronova, L. D. (1968). The effect of some pesticides on the soil invertebrate fauna in the south taiga zone in the Perm region (USSR). Pedobiologia 8, 507-525.

Voua Otomo, P., Wahl, J., and Maboeta, M. S. (2013). The enchytraeid reproduction test (ERT): a potentially quick and affordable tool for the 
assessment of metal contaminated soils in emerging economies. Bull. Environ. Contam. Toxicol. 91, 545-548. doi: 10.1007/s00128-013-1092-6

Waichman, A. V., Römbke, J., Ribeiro, M. O. A., and Nina, N. C. S. (2002). Use and fate of pesticides in the Amazon State, Brazil. Risk to human health and the environment. Environ. Sci. Pollut. Res. 9, 423-428. doi: 10.1007/BF02987596

Way, M. Y., and Scopes, N. E. A. (1968). Studies on the persistence and effects on soil fauna of some soil applied systemic insecticides. Ann. Appl. Biol. 62, 199-214. doi: 10.1111/j.1744-7348.1968.tb02816.x

Weber, G. (1953). Die Makrofauna leichter und schwerer Ackerböden und ihre Beein-flussung durch Pflanzenschutzmittel. Zeitschrift Pflanzenernährung Düngung Bodenkunde 61, 107-118. doi: 10.1002/jpln.19530610203

Westheide, W., Bethke Beilfuß, D., and Gebbe, J. (1991). Effects of Benomyl on reproduction and population structure of enchytraeid oligochaetes (Annelida). Sublethal tests on agar and soil. Comp. Biochem. Physiol. 100C, 221-224. doi: 10.1016/0742-8413(91)90157-o

Weuffen, W. (1968). Zusammenhänge zwischen chemischer Konstitution und keimwidriger Wirkung. 20. Archiv Experimentelle Veterinärmedizin 22, $127-132$.

Weyers, A., Römbke, J., Moser, T., and Ratte, H.-T. (2002). Statistical results and implications of the Enchytraeid Reproduction Test. Environ. Sci. Technol. 36, 2116-2121. doi: 10.1021/es000259h

Weyers, A., Sokull-Klüttgen, B., Knacker, T., Martin, S., and Van Gestel, C. A. M. (2004). Use of Terrestrial Model Ecosystem data in environmental risk assessment for industrial chemicals, biocides and plant protection products in the EU. Ecotoxicology 13, 163-176. doi: 10.1023/B:ECTX.0000012412.44625.69

Yang, D., Zhu, J., Fu, R., Wang, W., Guo, X., Wang, Z., et al. (2012a). Enchytraeidae Fridericia bulbosa as a new test species for soil ecotoxicity assessment. Chemosphere 88, 501-506. doi: 10.1016/j.chemosphere.2012.03.007

Yang, D., Zhu, J., Shen, G. X., Wang, W. H., Guo, X. P., Wang, Z. Q., et al. (2012b). The acute toxicity of single and combined exposure of mercury and bromoxynil on Fridericia bulbosa. Appl. Mech. Mater. 137, 280-285. doi: 10.4028/www. scientific.net/AMM.137.280

Zhao, S., Fung-Leung, W. P., Bittner, A., Ngo, K., and Liu, X. (2014). Comparison of RNA-Seq and microarray in transcriptome profiling of activated T cells. PLoS ONE 9:e78644. doi: 10.1371/journal.pone.0078644

Conflict of Interest Statement: The authors declare that the research was conducted in the absence of any commercial or financial relationships that could be construed as a potential conflict of interest.

Copyright (c) 2017 Römbke, Schmelz and Pélosi. This is an open-access article distributed under the terms of the Creative Commons Attribution License (CC BY). The use, distribution or reproduction in other forums is permitted, provided the original author(s) or licensor are credited and that the original publication in this journal is cited, in accordance with accepted academic practice. No use, distribution or reproduction is permitted which does not comply with these terms. 